\title{
LEVEL II SCOUR ANALYSIS FOR BRIDGE 9 (BLOOVT01020009) on STATE ROUTE 102, crossing the NULHEGAN RIVER, BLOOMFIELD, VERMONT
}

U.S. Geological Survey Open-File Report 97-389

Prepared in cooperation with

VERMONT AGENCY OF TRANSPORTATION and

FEDERAL HIGHWAY ADMINISTRATION 


\section{LEVEL II SCOUR ANALYSIS FOR BRIDGE 9 (BLOOVT01020009) on STATE ROUTE 102, crossing the NULHEGAN RIVER, BLOOMFIELD, VERMONT \\ By JOSEPH D. AYOTTE}

U.S. Geological Survey Open-File Report 97-389

Prepared in cooperation with

VERMONT AGENCY OF TRANSPORTATION

and

FEDERAL HIGHWAY ADMINISTRATION 


\title{
U.S. DEPARTMENT OF THE INTERIOR BRUCE BABBITT, Secretary
}

\author{
U.S. GEOLOGICAL SURVEY \\ Gordon P. Eaton, Director
}

For additional information write to:

District Chief

U.S. Geological Survey 361 Commerce Way

Pembroke, NH 03275-3718
Copies of this report may be purchased from:

U.S. Geological Survey

Branch of Information Services

Open-File Reports Unit

Box 25286

Denver, CO 80225-0286 


\section{CONTENTS}

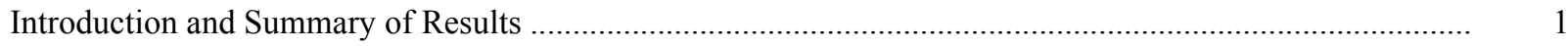

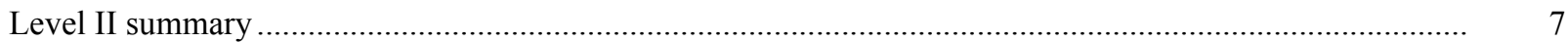

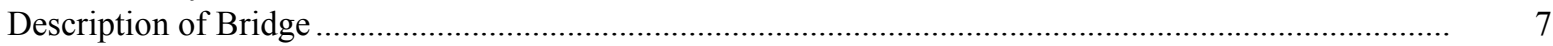

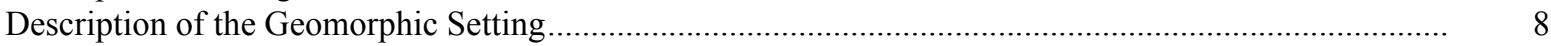

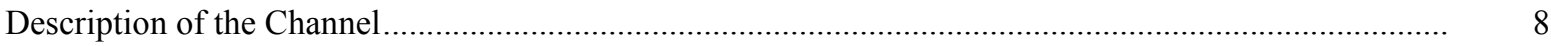

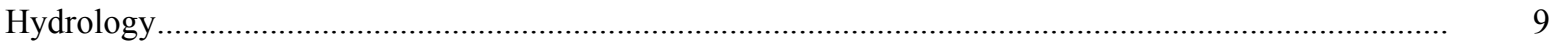

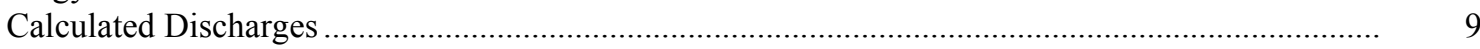

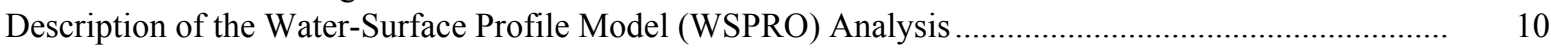

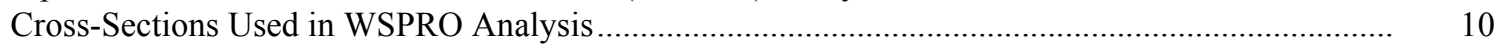

Data and Assumptions Used in WSPRO Model ..................................................................... 11

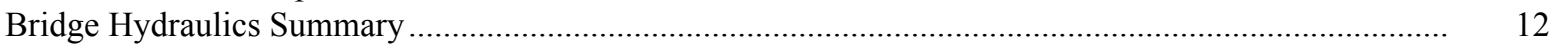

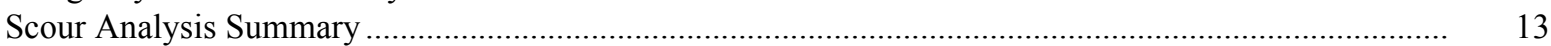

Special Conditions or Assumptions Made in Scour Analysis ...................................................... 13

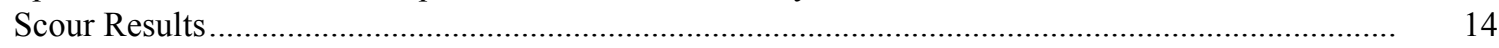

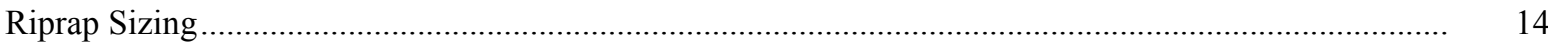

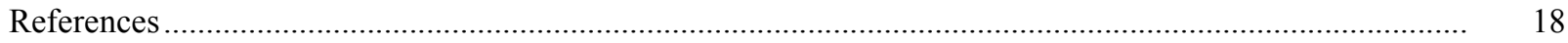

Appendixes:

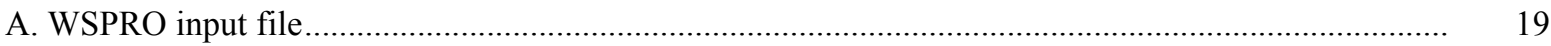

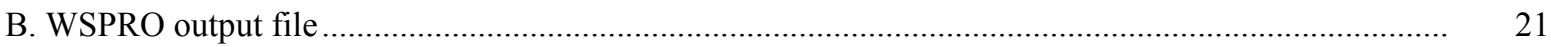

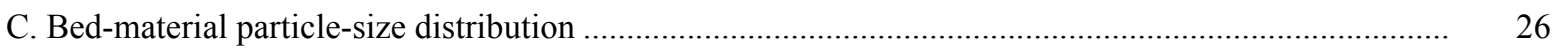

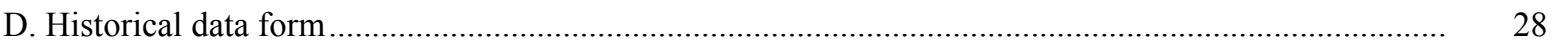

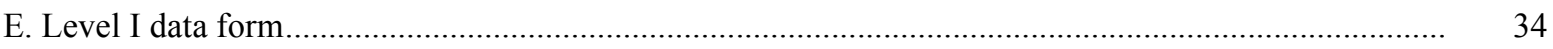

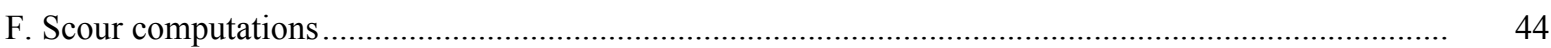

\section{FIGURES}

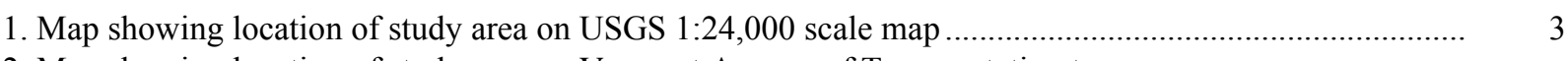

2. Map showing location of study area on Vermont Agency of Transportation town

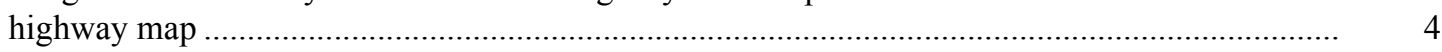

3. Structure BLOOVT01020009 viewed from upstream (July 6, 1995) ......................................................

4. Downstream channel viewed from structure BLOOVT01020009 (July 6, 1995) ................................. 5

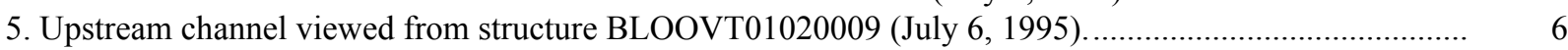

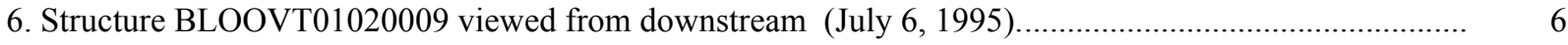

7. Water-surface profiles for the 100- and 500-year discharges at structure

BLOOVT01020009 on State Route 102, crossing the Nulhegan River,

Bloomfield, Vermont.

8. Scour elevations for the 100- and 500-year discharges at structure

BLOOVT01020009 on State Route 102, crossing the Nulhegan River,

Bloomfield, Vermont.

\section{TABLES}

1. Remaining footing/pile depth at abutments for the 100-year discharge at structure

BLOOVT01020009 on State Route 102, crossing the Nulhegan River,

Bloomfield, Vermont....

2. Remaining footing/pile depth at abutments for the 500-year discharge at structure

BLOOVT01020009 on State Route 102, crossing the Nulhegan River,

Bloomfield, Vermont.... 


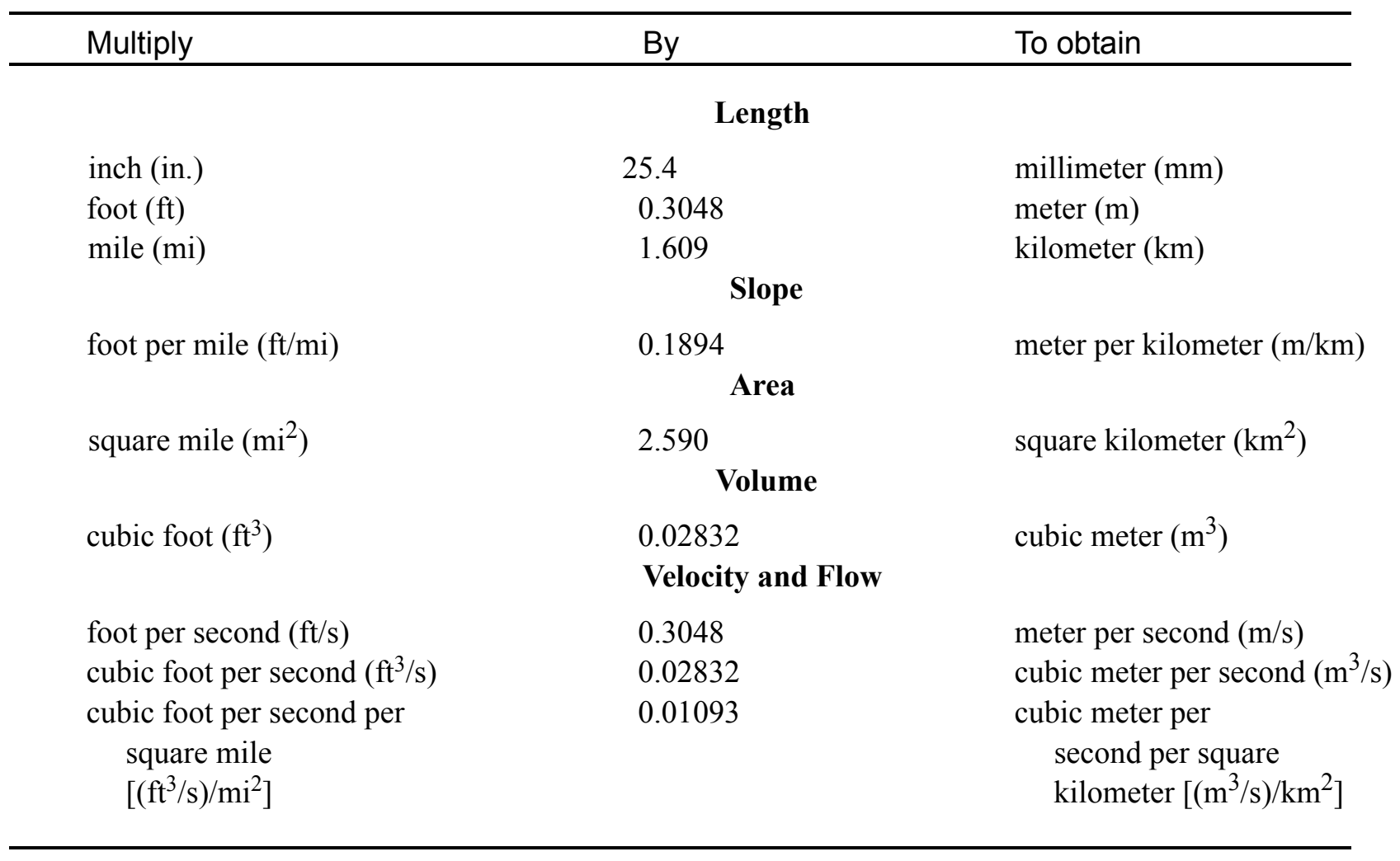

\section{OTHER ABBREVIATIONS}

$\begin{array}{lrlr}\mathrm{BF} & \text { bank full } & \text { LWW } & \text { left wingwall } \\ \mathrm{cfs} & \text { cubic feet per second } & \text { MC } & \text { main channel } \\ \mathrm{D}_{50} & \text { median diameter of bed material } & \text { RAB } & \text { right abutment } \\ \mathrm{DS} & \text { downstream } & \text { RABUT } & \text { face of right abutment } \\ \mathrm{elev} & \text { elevation } & \text { RB } & \text { right bank } \\ \mathrm{f} / \mathrm{p} & \text { flood plain } & \text { ROB } & \text { right overbank } \\ \mathrm{ft}^{2} & \text { square feet } & \text { RWW } & \text { right wingwall } \\ \mathrm{ft} / \mathrm{ft} & \text { feet per foot } & \text { TH } & \text { town highway } \\ \mathrm{JCT} & \text { junction } & \text { UB } & \text { under bridge } \\ \mathrm{LAB} & \text { left abutment } & \text { US } & \text { upstream } \\ \mathrm{LABUT} & \text { face of left abutment } & \text { USGS } & \text { United States Geological Survey } \\ \mathrm{LB} & \text { left bank } & \text { VTAOT Vermont Agency of Transportation } \\ \mathrm{LOB} & \text { left overbank } & \text { WSPRO } & \text { water-surface profile model }\end{array}$

In this report, the words "right" and "left" refer to directions that would be reported by an observer facing downstream. Sea level: In this report, "sea level" refers to the National Geodetic Vertical Datum of 1929-- a geodetic datum derived from a general adjustment of the first-order level nets of the United States and Canada, formerly called Sea Level Datum of 1929.

In the appendices, the above abbreviations may be combined. For example, USLB would represent upstream left bank. 


\title{
LEVEL II SCOUR ANALYSIS FOR BRIDGE 9 (BLOOVT01020009) ON STATE ROUTE 102, CROSSING THE NULHEGAN RIVER, BLOOMFIELD, VERMONT
}

\author{
By Joseph D. Ayotte
}

\section{INTRODUCTION AND SUMMARY OF RESULTS}

This report provides the results of a detailed Level II analysis of scour potential at structure BLOOVT01020009 on State Route 102 crossing the Nulhegan River, Bloomfield, Vermont (figures 1-8). A Level II study is a basic engineering analysis of the site, including a quantitative analysis of stream stability and scour (U.S. Department of Transportation, 1993). Results of a Level I scour investigation also are included in Appendix E of this report. A Level I investigation provides a qualitative geomorphic characterization of the study site. Information on the bridge, gleaned from Vermont Agency of Transportation (VTAOT) files, was compiled prior to conducting Level I and Level II analyses and is found in Appendix D.

The site is in the White Mountain section of the New England physiographic province in northeastern Vermont. The 144- $\mathrm{mi}^{2}$ drainage area is in a predominantly rural and forested basin. In the vicinity of the study site, the surface cover is forest except for the downstream right bank area which is shrub and brush land. The Nulhegan River flows into the Connecticut River 210 feet downstream of this bridge.

In the study area, the Nulhegan River has an incised, sinuous channel with a slope of approximately $0.005 \mathrm{ft} / \mathrm{ft}$, an average channel top width of $164 \mathrm{ft}$ and an average channel depth of $5 \mathrm{ft}$. The predominant channel bed material is cobble with a median grain size $\left(D_{50}\right)$ of $152 \mathrm{~mm}(0.498 \mathrm{ft})$. The geomorphic assessment at the time of the Level I and Level II site visit on July 6, 1995, indicated that the reach was laterally unstable. This was due to numerous point bars and side bars indicating an unstable thalweg.

The State Route 102 crossing of the Nulhegan River is a 134-ft-long, two-lane bridge consisting of one 130-foot steel-truss span (Vermont Agency of Transportation, written communication, August 4, 1994). The field measured clear span was $131.6 \mathrm{ft}$. The bridge is supported by vertical, concrete abutments with rip-rapped spill-through slopes. The channel is skewed approximately 25 degrees to the opening while the measured opening-skew-toroadway is 5 degrees. 
A scour hole $3.5 \mathrm{ft}$ deeper than the mean thalweg depth was observed $250 \mathrm{ft}$ upstream during the Level I assessment. It was noted that the scour was localized on the right bank side and due to the presence of an old abutment. Scour countermeasures include the type-3 stone-fill (less than 48 inches diameter) which forms the spill-through slopes of the abutments. Additional details describing conditions at the site are included in the Level II Summary and Appendices

$\mathrm{D}$ and $\mathrm{E}$.

Scour depths and rock rip-rap sizes were computed using the general guidelines described in Hydraulic Engineering Circular 18 (Richardson and others, 1995). Total scour at a highway crossing is comprised of three components: 1) long-term streambed degradation; 2) contraction scour (due to accelerated flow caused by a reduction in flow area at a bridge) and; 3) local scour (caused by accelerated flow around piers and abutments). Total scour is the sum of the three components. Equations are available to compute depths for contraction and local scour and a summary of the results of these computations follows.

Computed contraction scour for all modelled flows was zero ft. Abutment scour ranged from 4.5 to $5.0 \mathrm{ft}$ at the left abutment and 9.6 to $11.4 \mathrm{ft}$ at the right abutment. The worst-case abutment scour occurred at the 500-year discharge. Additional information on scour depths and depths to armoring are included in the section titled "Scour Results". Scoured streambed elevations, based on the calculated scour depths, are presented in tables 1 and 2. A cross-section of the scour computed at the bridge is presented in figure 8. Scour depths were calculated assuming an infinite depth of erosive material and a homogeneous particlesize distribution.

It is generally accepted that the Froehlich equation (abutment scour) gives "excessively conservative estimates of scour depths" (Richardson and others, 1995, p. 47). Usually, computed scour depths are evaluated in combination with other information including (but not limited to) historical performance during flood events, the geomorphic stability assessment, existing scour protection measures, and the results of the hydraulic analyses. Therefore, scour depths adopted by VTAOT may differ from the computed values documented herein. 


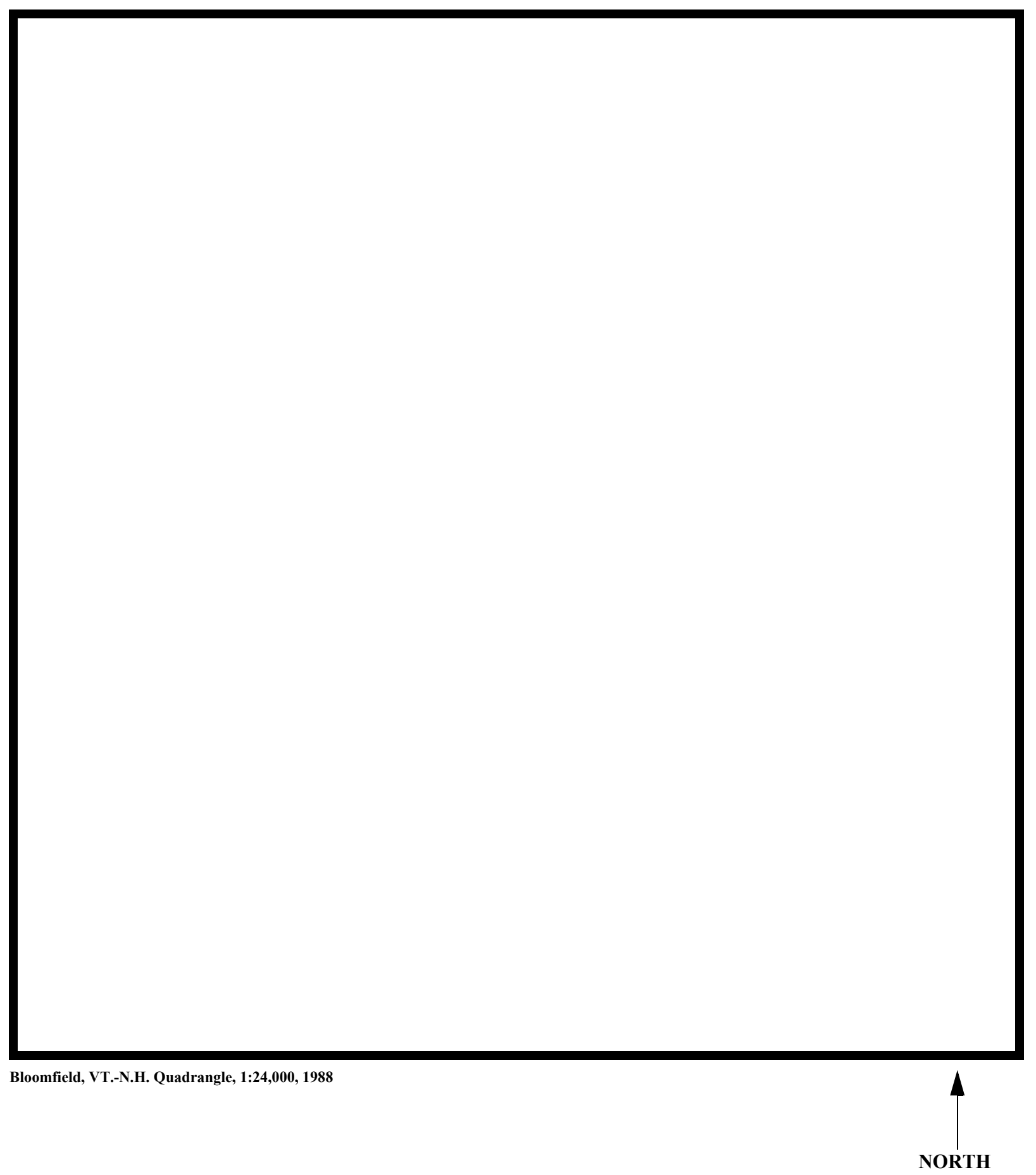

Figure 1. Location of study area on USGS 1:24,000 scale map. 
Figure 2. Location of study area on Vermont Agency of Transportation town highway map. 

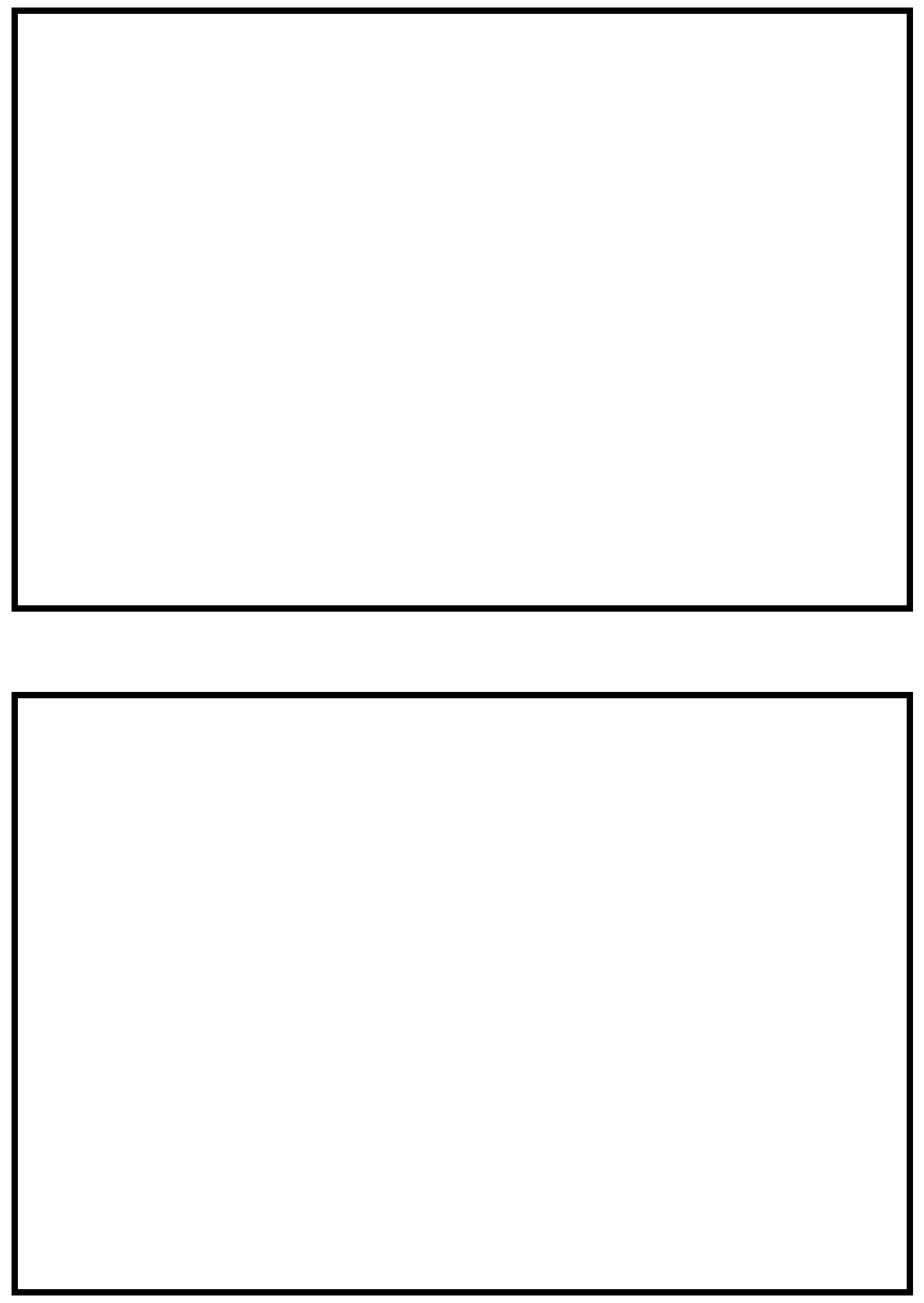

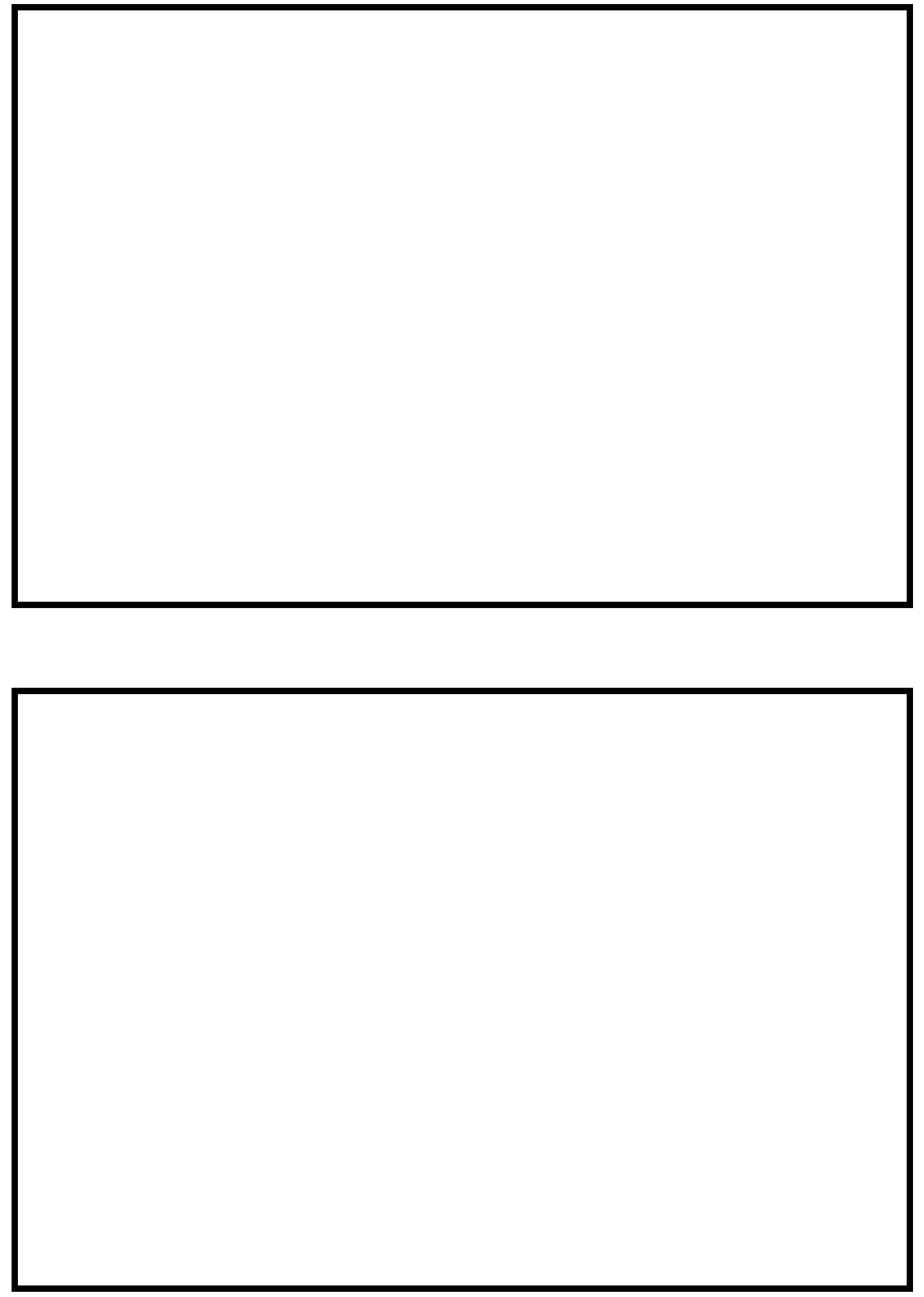


\section{LEVEL II SUMMARY}

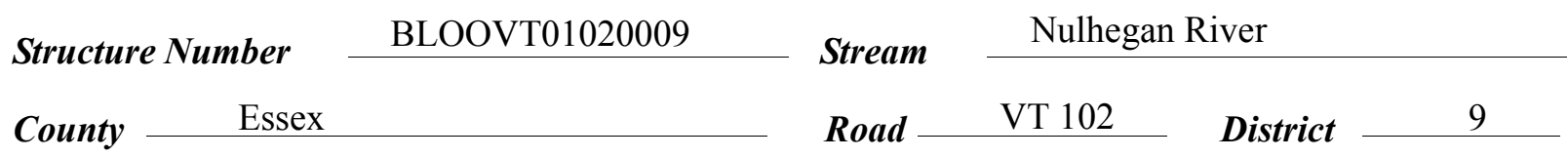

\section{Description of Bridge}

Bridge length $\frac{134}{f t}$ Bridge width $\stackrel{24.4}{f t}$ Max span length $\frac{130}{f t}$ Alignment of bridge to road (on curve or straight) spill-through

Abutment type

Stone fill on abutment?

Yes

\section{Embankment type} straight

namonintion sfoten a fill

Dato af insnortian
There are spill-through slopes at each abutment consisting of type-3

$$
\text { sloping }
$$

stone-fill.

Abutments are vertical concrete with rip-rapped spill-

through slopes.

\section{$\mathrm{Y}$}

Is bridge skewed to flood flow according to $\mathrm{N} \quad$ r survey?

Angle

Debris accumulation on bridge at time of Level I or Level II site visit:

\begin{tabular}{|c|c|c|c|}
\hline & $\begin{array}{c}\text { Date of incnortion } \\
07 / 06 / 95 \\
\end{array}$ & $\begin{array}{l}\text { Percent of almmust } \\
\text { blocked nortzontatly }\end{array}$ & $\begin{array}{l}\text { Percent of } 0 \\
\text { blocked verticatty }\end{array}$ \\
\hline Level I & 07/06/95 & 0 & 0 \\
\hline $\begin{array}{l}\text { Level II } \\
\text { low. }\end{array}$ & \multicolumn{3}{|c|}{ Moderate, but it is noted that the capture efficiency of the bridge is } \\
\hline
\end{tabular}

July 6, 1995. The confluence with the Connecticut River is $210 \mathrm{ft}$ downstream.

Doscriho anv fonturos noar ar at tho hridoo that mav affort flow, (includo ohsorvation dato) 


\section{Description of the Geomorphic Setting}

General topography The channel is located within a 1000 foot-wide, moderate relief valley at the confluence with the Connecticut River with moderate valley walls.

Geomorphic conditions at bridge site: downstream (DS), upstream (US)

Date of inspection $\quad 07 / 06 / 95$

DS left: $\quad$ Moderately sloped overbank

DS right: $\quad$ Moderately sloped overbank

US left: $\quad$ Moderately sloped overbank

US right: $\quad$ Steep bank to over bank

\section{Description of the Channel}

$\begin{array}{llll}\text { Average top width } & 164 & \text { Average depth } & \frac{5}{\text { Gravel/Cobbles }} \\ & \text { Cobbles }\end{array}$

Predominant bed material

Bank material

Sinuous with semi-

alluvial to allúvial channel boundaries and a moderately wide flood plain.

$07 / 06 / 95$

Vegetative co 1 Trees and brush

DS left: $\quad$ Trees and brush

DS right: $\quad$ Trees and brush

US left: $\quad$ Shrubs and brush

US right: $\quad$ N

Do banks appear stable? On 07/06/95, moderate fluvial erosion was noted along the

downstream right bank. Bank cutting is occurring along the left bank from $71 \mathrm{ft}$ upstream of the
date of observatiton. bridge to $145 \mathrm{ft}$ downstream.

The assessment of $07 /$

06/95 noted large cobble point bars in the US and DS reaches as well as under the bridge. Describe any obstructions in channel and date of observation. 


\title{
Hydrology
}

Drainage area $\frac{144}{m i^{2}}$

Percentage of drainage area in physiographic provinces: (approximate)

Physiographic province/section

New England/White Mountain
Percent of drainage area 100

\begin{abstract}
Is drainage area considered rural or urban? Rural Describe any significant urbanization: None
\end{abstract}

Is there a

Is there a USGS gage on the stream of interest? USGS gage description

USGS gage number

Gage drainage area $\mathrm{mi}^{2}$

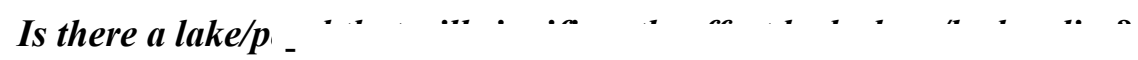

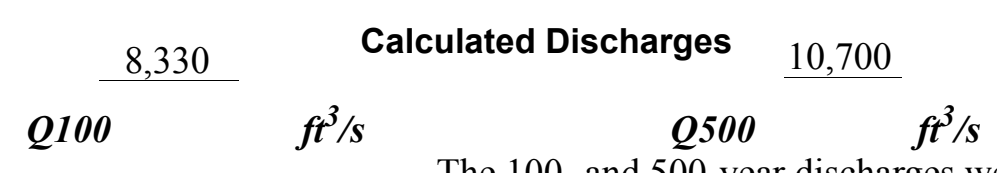

The 100- and 500-year discharges were the median

of several empirical methods for estimating flood frequencies (Benson, 1962; Johnson and Tasker, 1974; Potter, 1957a\&b; Talbot, 1887) applicable to this site.The flood frequency curves developed for this site were graphically extrapolated to the 500 -year return period. 


\section{Description of the Water-Surface Profile Model (WSPRO) Analysis}

Datum for WSPRO analysis (USGS survey, sea level, VTAOT plans)

USGS Survey

Datum tie between USGS survey and VTAOT plans

Add $1.0 \mathrm{ft}$ to USGS datum to

obtain VTAOT datum.

Description of reference marks used to determine USGS datum. $\quad$ RM1 is a chiseled X on top of the upstream end of the right abutment (elev. $195.96 \mathrm{ft}$, VTAOT survey datum). RM2 is a chiseled X on top of the upstream end of the left abutment (elev. $195.87 \mathrm{ft}$, VTAOT survey datum).

\section{Cross-Sections Used in WSPRO Analysis}

\begin{tabular}{ccll}
\hline${ }^{1}$ Cross-section & $\begin{array}{c}\text { Section } \\
\text { Reference } \\
\text { Distance } \\
\text { (SRD) in feet }\end{array}$ & $\begin{array}{c}{ }^{2} \text { Cross-section } \\
\text { development }\end{array}$ & \multicolumn{1}{c}{ Comments } \\
\hline EXIT1 & -90 & 1 & Exit section \\
FULLV & 0 & 2 & $\begin{array}{l}\text { Downstream Full-valley } \\
\text { section (Templated from } \\
\text { EXIT1) }\end{array}$ \\
BRIDG & 0 & 1 & $\begin{array}{l}\text { Bridge section } \\
\text { Road Grade section }\end{array}$ \\
RDWAY & 12 & 1 & $\begin{array}{l}\text { Modelled Approach sec- } \\
\text { tion (Templated from } \\
\text { APTEM) }\end{array}$ \\
APTEM & 155 & 2 & $\begin{array}{l}\text { Approach section as sur- } \\
\text { veyed (Used as a tem- } \\
\text { plate) }\end{array}$ \\
\hline
\end{tabular}

${ }^{1}$ For location of cross-sections see plan-view sketch included with Level I field form, Appendix E. For more detail on how cross-sections were developed see WSPRO input file. 


\section{Data and Assumptions Used in WSPRO Model}

Hydraulic analyses of the reach were done by use of the Federal Highway Administration's WSPRO step-backwater computer program (Shearman and others, 1986, and Shearman, 1990). The analyses reported herein reflect conditions existing at the site at the time of the study. Furthermore, in the development of the model it was necessary to assume no accumulation of debris or ice at the site. Results of the hydraulic model are presented in the Bridge Hydraulic Summary, Appendix B, and figure 7.

Channel roughness factors (Manning's " $n$ ") used in the hydraulic model were estimated using field inspections at each cross section following the general guidelines described by Arcement and Schneider (1989). Final adjustments to the values were made during the modelling of the reach. Channel " $\mathrm{n}$ " values for the reach ranged from 0.040 to 0.060 , and overbank " $n$ " values ranged from 0.040 to 0.080 .

Normal depth at the exit section (EXIT1) was assumed as the starting water surface. This depth was computed by use of the slope-conveyance method outlined in the user's manual for WSPRO (Shearman, 1990). The slope used was $0.005 \mathrm{ft} / \mathrm{ft}$, which was estimated from surveyed channel thalweg points between the bridge and the exit sections. This slope matched the channel slope upstream of the bridge measured from the topographical map (USGS, 1988).

Using normal depth as the starting water-surface ignores the effects of backwater from the Connecticut River, $210 \mathrm{ft}$ downstream. However, due to the difference in drainage areas at the confluence and the significant storage in the Connecticut River basin, the extent of backwater from the Connecticut River while the Nulhegan River is at a peak discharge is unknown. Thus, normal depth is appropriate.

The surveyed approach section (APTEM) was moved along the approach channel slope $(0.011 \mathrm{ft} / \mathrm{ft})$ to establish the modelled approach section (APPRO), one bridge length upstream of the upstream face as recommended by Shearman and others (1986). This location also provides a consistent method for determining scour variables. 


\section{Bridge Hydraulics Summary}

\begin{tabular}{lll} 
Average bridge embankment elevation & \multicolumn{1}{c}{195.5} \\
Average low steel elevation & 191.0 & $\boldsymbol{f t}$
\end{tabular}

100-year discharge $\quad 8,330 \quad \mathrm{ft}^{3} / \mathrm{s}$

Water-surface elevation in bridge opening $\quad 187.9 f t$

Road overtopping? ___ N Discharge over road___-- $\mathrm{ft}^{3} / \mathrm{s}$

Area of flow in bridge opening $\quad 746 \quad \mathrm{ft}^{2}$

Average velocity in bridge opening $11.2 \quad \mathrm{ft} / \mathrm{s}$

Maximum WSPRO tube velocity at bridge $\quad 13.4 \mathrm{ft} / \mathrm{s}$

Water-surface elevation at Approach section with bridge $\quad 190.2$

Water-surface elevation at Approach section without bridge $\quad 189.6$

Amount of backwater caused by bridge $\quad 0.6$ it

500-year discharge $\quad 10,700 \quad \mathrm{ft}^{3} / \mathrm{s}$

Water-surface elevation in bridge opening $\quad 188.3 \mathrm{ft}$

Road overtopping? ___ N Discharge over road ___ -- $\mathrm{ft}^{3} / \mathrm{s}$

Area of flow in bridge opening $\quad 791 \quad \mathrm{ft}^{2}$

Average velocity in bridge opening $13.5 \mathrm{ft} / \mathrm{s}$

Maximum WSPRO tube velocity at bridge 16.2 _s

Water-surface elevation at Approach section with bridge 191.6

Water-surface elevation at Approach section without bridge $\quad 190.3$

Amount of backwater caused by bridge 1.3 .

Incipient overtopping discharge $\quad$ N/A $f^{3} / s$

Water-surface elevation in bridge opening $\quad--\quad t$

Area of flow in bridge opening _ $\quad--\quad \mathrm{ft}^{2}$

Average velocity in bridge opening $\quad--\quad f t / s$

Maximum WSPRO tube velocity at bridge $\quad--\quad f t / s$

Water-surface elevation at Approach section with bridge

Water-surface elevation at Approach section without bridge

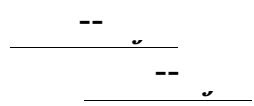

Amount of backwater caused by bridge _ $\quad-{ }_{-}$, t 


\section{Scour Analysis Summary}

\section{Special Conditions or Assumptions Made in Scour Analysis}

Scour depths were computed using the general guidelines described in Hydraulic Engineering Circular 18 (Richardson and others, 1995). Scour depths were calculated assuming an infinite depth of erosive material and a homogeneous particle-size distribution. The results of the scour analysis are presented in tables 1 and 2 and a graph of the scour depths is presented in figure 8 .

Contraction scour was computed by use of the clear-water contraction scour equation (Richardson and others, 1995, p. 32, equation 20). In this case, computed contraction scour was zero feet for both of the modelled discharges.

Abutment scour at the right abutment was computed by use of the Froehlich equation (Richardson and others, 1995, p. 48, equation 28). Variables for the Froehlich equation include the Froude number of the flow approaching the embankments, the length of the embankment blocking flow, and the depth of flow approaching the embankment less any roadway overtopping.

Scour at the left abutment was computed by use of the HIRE equation (Richardson and others, 1995, p. 49, equation 29) because the HIRE equation is recommended when the length to depth ratio of the embankment blocking flow exceeds 25 . The variables used by the HIRE abutment-scour equation are defined the same as those defined for the Froehlich abutment-scour equation. 


\section{Scour Results}

100-yr discharge 500-yr discharge

Incipient

Contraction scour:

(Scour depths in feet)

Main channel

Live-bed scour

Clear-water scour

Depth to armoring

Left overbank

Right overbank

Local scour:

Abutment scour

Left abutment

4.5

5.0

9.6-

11.4-

\section{Right abutment}

Pier scour

Pier 1

Pier 2

Pier 3

Abutments:

Left abutment

Right abutment

Piers:

Pier 1

Pier 2

overtopping discharge
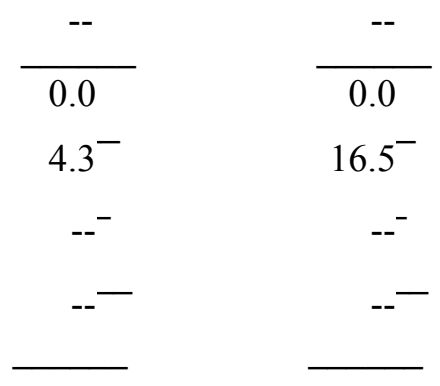

$16.5^{-}$

---

--

$--$
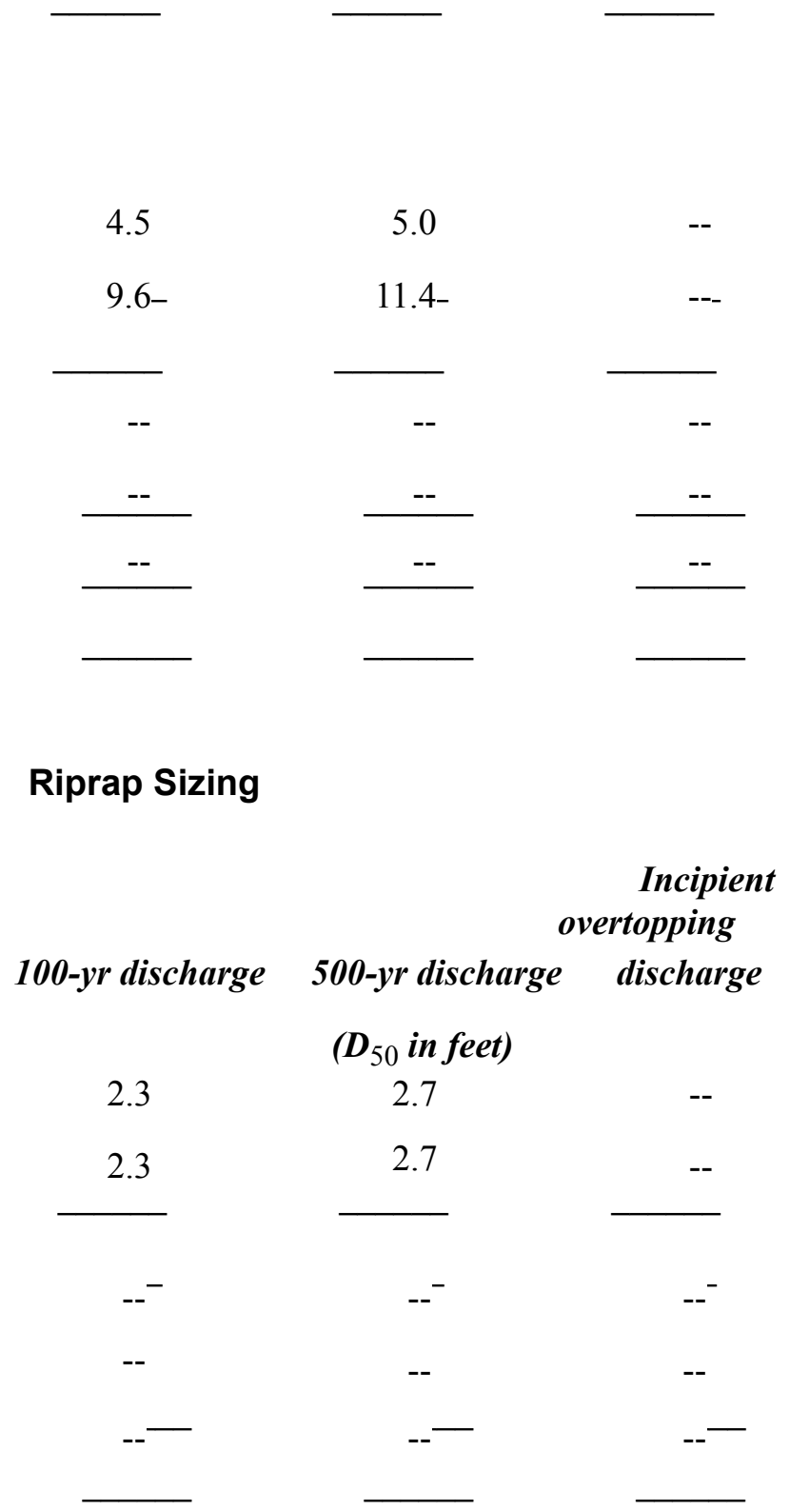

Incipient

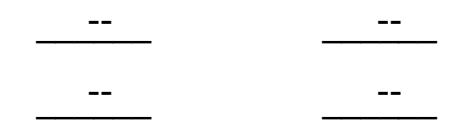

$\longrightarrow$

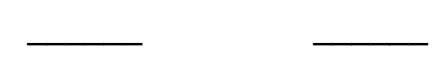

\section{Riprap Sizing}




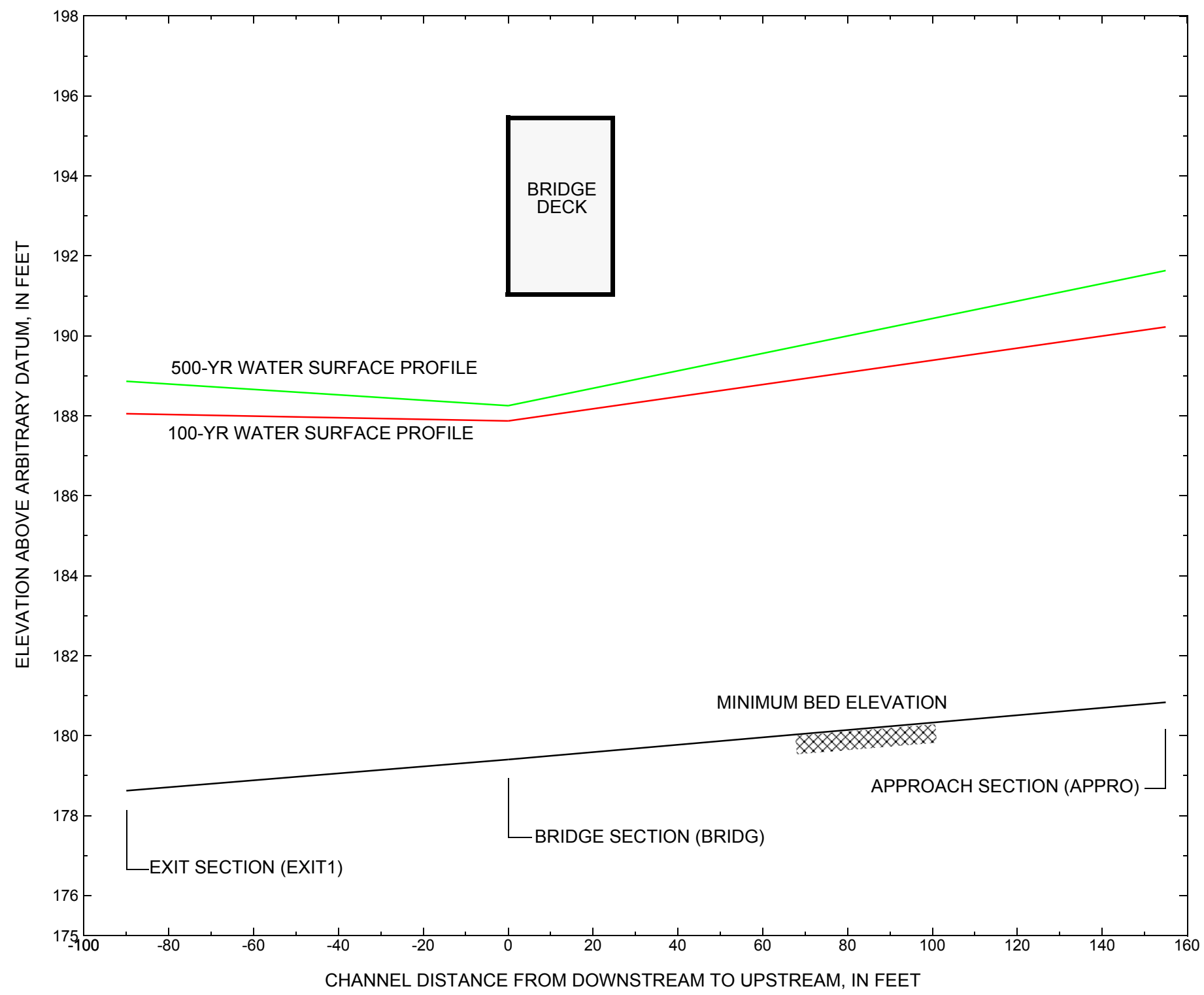

Figure 7. Water-surface profiles for the 100- and 500-yr discharges at structure BLOOVT01020009 on State Route 102, crossing the Nulhegan River, Bloomfield, Vermont. 


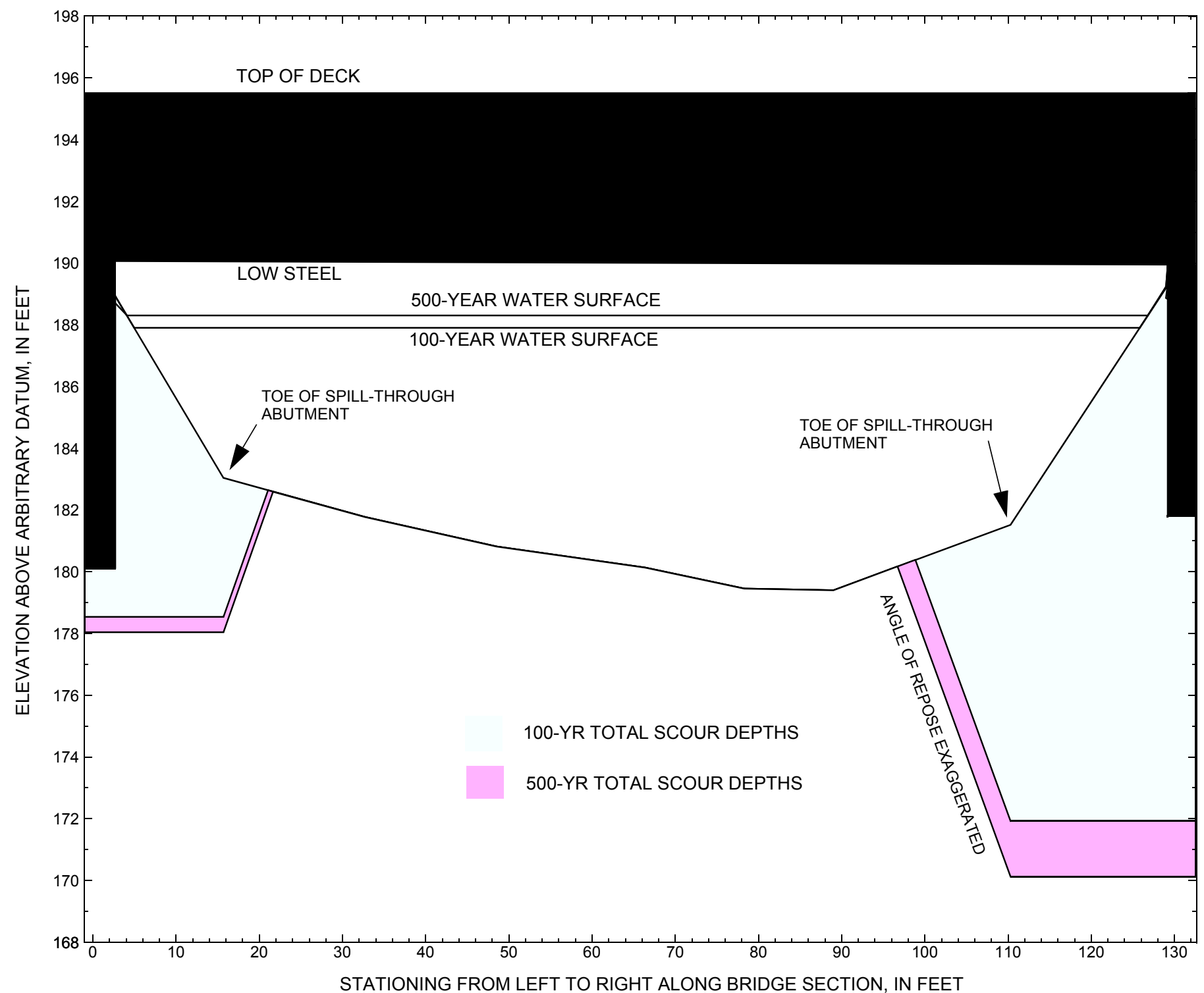

Figure 8. Scour elevations for the 100-yr and 500-yr discharges at structure BLOOVT01020009 on State Route 102, crossing the Nulhegan River, Bloomfield, Vermont. 
Table 1. Remaining footing/pile depth at abutments for the 100-year discharge at structure BLOOVT01020009 on State Route 102, crossing the Nulhegan River, Bloomfield, Vermont.

[VTAOT, Vermont Agency of Transportation; --,no data]

\begin{tabular}{|c|c|c|c|c|c|c|c|c|c|c|c|}
\hline Description & Station ${ }^{1}$ & $\begin{array}{l}\text { VTAOT } \\
\text { bridge seat } \\
\text { elevation } \\
\text { (feet) }\end{array}$ & $\begin{array}{l}\text { Surveyed } \\
\text { minimum } \\
\text { low-chord } \\
\text { elevation }{ }^{2} \\
\text { (feet) }\end{array}$ & $\begin{array}{l}\text { Bottom of } \\
\text { footing } \\
\text { elevation } \\
\text { (feet) }\end{array}$ & $\begin{array}{c}\text { Channel } \\
\text { elevation at } \\
\text { abutment/ } \\
\text { pier }^{2} \\
\text { (feet) }\end{array}$ & $\begin{array}{l}\text { Contraction } \\
\text { scour depth } \\
\text { (feet) }\end{array}$ & $\begin{array}{l}\text { Abutment } \\
\text { scour } \\
\text { depth } \\
\text { (feet) }\end{array}$ & $\begin{array}{l}\text { Pier } \\
\text { scour } \\
\text { depth } \\
\text { (feet) }\end{array}$ & $\begin{array}{l}\text { Depth of } \\
\text { total scour } \\
\text { (feet) }\end{array}$ & $\begin{array}{c}\text { Elevation of } \\
\text { scour }^{2} \\
\text { (feet) }\end{array}$ & $\begin{array}{c}\text { Remaining } \\
\text { footing/pile } \\
\text { depth } \\
\text { (feet) }\end{array}$ \\
\hline \multicolumn{12}{|c|}{100 -yr. discharge is 8,330 cubic-feet per second } \\
\hline Left abutment & 0.0 & 191.1 & 190.1 & 180.1 & -- & -- & -- & -- & -- & -- & -1.6 \\
\hline Toe of spill-thru & 15.7 & -- & -- & -- & 183.0 & 0.0 & 4.5 & -- & 4.5 & 178.5 & -1.6 \\
\hline Toe of spill-thru & 110.3 & -- & -- & -- & 181.5 & 0.0 & 9.6 & -- & 9.6 & 171.9 & -9.9 \\
\hline Right abutment & 131.6 & 191.1 & 190.0 & 181.8 & -- & -- & -- & -- & -- & -- & -9.9 \\
\hline
\end{tabular}

1.Measured along the face of the most constricting side of the bridge.

2.Arbitrary datum for this study.

Table 2. Remaining footing/pile depth at abutments for the 500-year discharge at structure BLOOVT01020009 on State Route 102, crossing the Nulhegan River, Bloomfield, Vermont.

[VTAOT, Vermont Agency of Transportation; --, no data]

\begin{tabular}{|c|c|c|c|c|c|c|c|c|c|c|c|}
\hline Description & Station $^{1}$ & $\begin{array}{c}\text { VTAOT } \\
\text { bridge seat } \\
\text { elevation } \\
\text { (feet) }\end{array}$ & $\begin{array}{l}\text { Surveyed } \\
\text { minimum } \\
\text { low-chord } \\
\text { elevation }{ }^{2} \\
\text { (feet) }\end{array}$ & $\begin{array}{c}\text { Bottom of } \\
\text { footing } \\
\text { elevation } \\
\text { (feet) }\end{array}$ & $\begin{array}{l}\text { Channel } \\
\text { elevation at } \\
\text { abutment/ } \\
\text { pier }^{2} \\
\text { (feet) }\end{array}$ & $\begin{array}{l}\text { Contraction } \\
\text { scour depth } \\
\text { (feet) }\end{array}$ & $\begin{array}{l}\text { Abutment } \\
\text { scour } \\
\text { depth } \\
\text { (feet) }\end{array}$ & $\begin{array}{l}\text { Pier } \\
\text { scour } \\
\text { depth } \\
\text { (feet) }\end{array}$ & $\begin{array}{l}\text { Depth of } \\
\text { total scour } \\
\text { (feet) }\end{array}$ & $\begin{array}{c}\text { Elevation of } \\
\text { scour }^{2} \\
\text { (feet) }\end{array}$ & $\begin{array}{c}\text { Remaining } \\
\text { footing/pile } \\
\text { depth } \\
\text { (feet) }\end{array}$ \\
\hline \multicolumn{12}{|c|}{500 -yr. discharge is 10,700 cubic-feet per second } \\
\hline Left abutment & 0.0 & 191.1 & 190.1 & 180.1 & -- & -- & -- & -- & -- & -- & -2.1 \\
\hline Toe of spill-thru & 15.7 & -- & -- & -- & 183.0 & 0.0 & 5.0 & -- & 5.0 & 178.0 & -2.1 \\
\hline Toe of spill-thru & 110.3 & -- & -- & -- & 181.5 & 0.0 & 11.4 & -- & 11.4 & 170.1 & -11.7 \\
\hline Right abutment & 131.6 & 191.1 & 190.0 & 181.8 & -- & -- & -- & -- & -- & -- & -11.7 \\
\hline
\end{tabular}

1.Measured along the face of the most constricting side of the bridge.

2.Arbitrary datum for this study. 


\section{SELECTED REFERENCES}

Arcement, G.J., Jr., and Schneider, V.R., 1989, Guide for selecting Manning's roughness coefficients for natural channels and flood plains: U.S. Geological Survey Water-Supply Paper 2339, 38 p.

Barnes, H.H., Jr., 1967, Roughness characteristics of natural channels: U.S. Geological Survey Water-Supply Paper 1849,213 p.

Benson, M. A., 1962, Factors Influencing the Occurrence of Floods in a Humid Region of Diverse Terrain: U.S. Geological Survey WaterSupply Paper 1580-B, 64 p.

Brown, S.A. and Clyde, E.S., 1989, Design of riprap revetment: Federal Highway Administration Hydraulic Engineering Circular No. 11, Publication FHWA-IP-89-016, 156 p.

Federal Highway Administration, 1983, Runoff estimates for small watersheds and development of sound design: Federal Highway Administration Report FHWA-RD-77-158

Froehlich, D.C., 1989, Local scour at bridge abutments in Ports, M.A., ed., Hydraulic Engineering--Proceedings of the 1989 National Conference on Hydraulic Engineering: New York, American Society of Civil Engineers, p. 13-18.

Hayes, D.C.,1993, Site selection and collection of bridge-scour data in Delaware, Maryland, and Virginia: U.S. Geological Survey WaterResources Investigation Report 93-4017, 23 p.

Interagency Advisory Committee on Water Data, 1982, Guidelines for determining flood flow frequency: U.S. Geological Survey, Bulletin 17B of the Hydrology Subcommittee, 190 p.

Johnson, C.G. and Tasker, G.D.,1974, Progress report on flood magnitude and frequency of Vermont streams: U.S. Geological Survey OpenFile Report 74-130, 37 p.

Lagasse, P.F., Schall, J.D., Johnson, F., Richardson, E.V., Chang, F., 1995, Stream Stability at Highway Structures: Federal Highway Administration Hydraulic Engineering Circular No. 20, Publication FHWA-IP-90-014, 144 p.

Laursen, E.M., 1960, Scour at bridge crossings: Journal of the Hydraulics Division, American Society of Civil Engineers, v. 86, no. HY2, p. 39-53.

Potter, W. D., 1957a, Peak rates of runoff in the Adirondack, White Mountains, and Maine woods area, Bureau of Public Roads

Potter, W. D., 1957b, Peak rates of runoff in the New England Hill and Lowland area, Bureau of Public Roads

Richardson, E.V. and Davis, S.R., 1995, Evaluating scour at bridges: Federal Highway Administration Hydraulic Engineering Circular No. 18, Publication FHWA-IP-90-017, 204 p.

Richardson, E.V., Simons, D.B., and Julien, P.Y., 1990, Highways in the river environment: Federal Highway Administration Publication FHWA-HI-90-016.

Ritter, D.F., 1984, Process Geomorphology: W.C. Brown Co., Debuque, Iowa, 603 p.

Shearman, J.O., 1990, User's manual for WSPRO--a computer model for water surface profile computations: Federal Highway Administration Publication FHWA-IP-89-027, 187 p.

Shearman, J.O., Kirby, W.H., Schneider, V.R., and Flippo, H.N., 1986, Bridge waterways analysis model; research report: Federal Highway Administration Publication FHWA-RD-86-108, 112 p.

Talbot, A.N., 1887, The determination of water-way for bridges and culverts.

U.S. Department of Transportation, 1993, Stream stability and scour at highway bridges, Participant Workbook: Federal Highway Administration Publication FHWA HI-91-011.

U.S. Geological Survey, 1988, Bloomfield, Vermont 7.5 Minute Series quadrangle map: U.S. Geological Survey Topographic Maps, Scale $1: 24,000$. 


\section{APPENDIX A: \\ WSPRO INPUT FILE}




\section{WSPRO INPUT FILE}

XS

GR

GR

GR

GR

GR

$\mathrm{N}$

SA

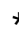

XS

*

*

$\mathrm{BR}$

GR

GR

GR

GR

GR

*

CD

$\mathrm{N}$

*

*

*

$\mathrm{XR}$

GR

GR

GR

GR

GR

*

$\mathrm{XT}$

GR

GR

GR

GR

*

AS

GT

$\mathrm{N}$

SA

*

HP 1 BRIDG

HP 2 BRIDG

HP 1 APPRO

HP 2 APPRO

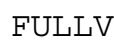

APPRO

U.S. Geological Survey WSPRO Input File blo0009.wsp Hydraulic analysis for structure BLOOVT01020009 Date: 11-APR-96 Bloomfield Br 9, crossing Nulhegan R., VT Rte 102 JDA $8330.0 \quad 10700.0$ $0.005 \quad 0.005$

$\begin{array}{lllllllllllllllllllll}6 & 29 & 30 & 552 & 553 & 551 & 5 & 16 & 17 & 13 & 3 & * & 15 & 14 & 23 & 21 & 11 & 12 & 4 & 7 & 3\end{array}$ EXIT1 $-90 \quad 0$.

$$
\begin{array}{rrrr}
-200.0, & 188.48 & -41.9, & 187.16 \\
42.1, & 180.84 & 45.0, & 180.71 \\
86.0, & 178.88 & 99.0, & 178.62 \\
118.7, & 186.09 & 167.9, & 188.08 \\
449.6, & 194.72 & 559.7, & 198.85 \\
0.040 & -41.9 & 0.045 & 0.040 \\
& 118.7 &
\end{array}
$$

$-6.1,183.38$

$59.0,180.29$ $109.7,180.68$ $194.0,193.57$
$-244.5,193.03-190.7,192.14$

$-105.6,197.44 \quad-49.3,197.63$

$143.1,197.87 \quad 143.4,195.40$

$297.2,214.24$

$-355.1,198.68$

$-149.7,193.92$

$1.1,197.67$

$-289.1,194.00$

$-138.6,196.98$

$133.0,197.54$

$180.4,195.66183 .0,196.90$ $\begin{array}{rr}2.6, & 190.10 \\ 48.5, & 180.82\end{array}$

$103.3,180.83$

$129.9,189.96$
$11.7,181.36$

$76.7,179.64$ $114.0,182.20$ $356.2,192.88$

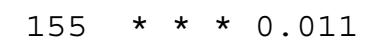

0.080

0.060

$-13.1$

187.871187 .87
$187.87 \star \star 8330$
190.221190 .22
$190.22 \star \star 8330$ 


\section{APPENDIX B: \\ WSPRO OUTPUT FILE}


WSPRO OUTPUT FILE

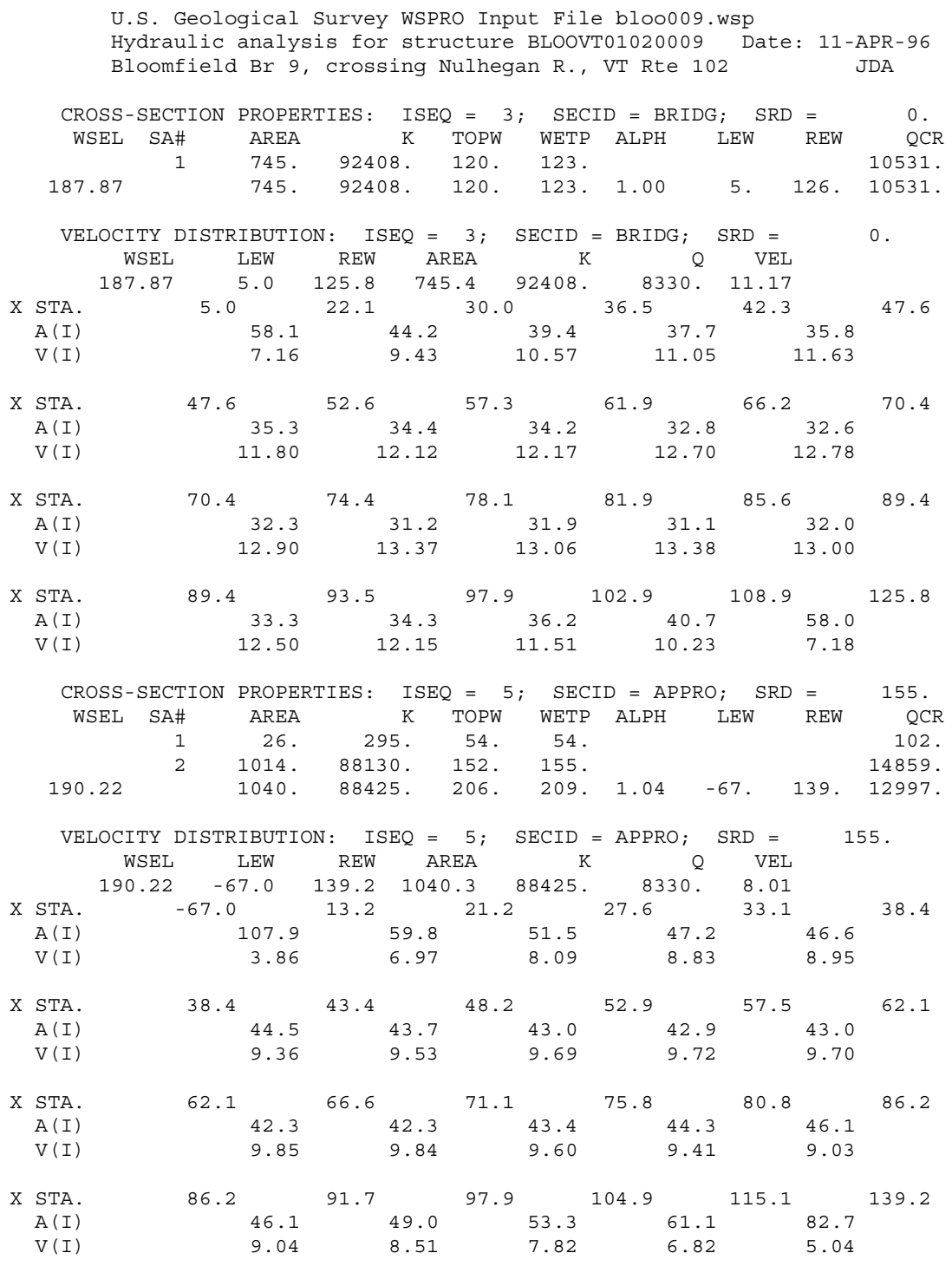


WSPRO OUTPUT FILE (continued)

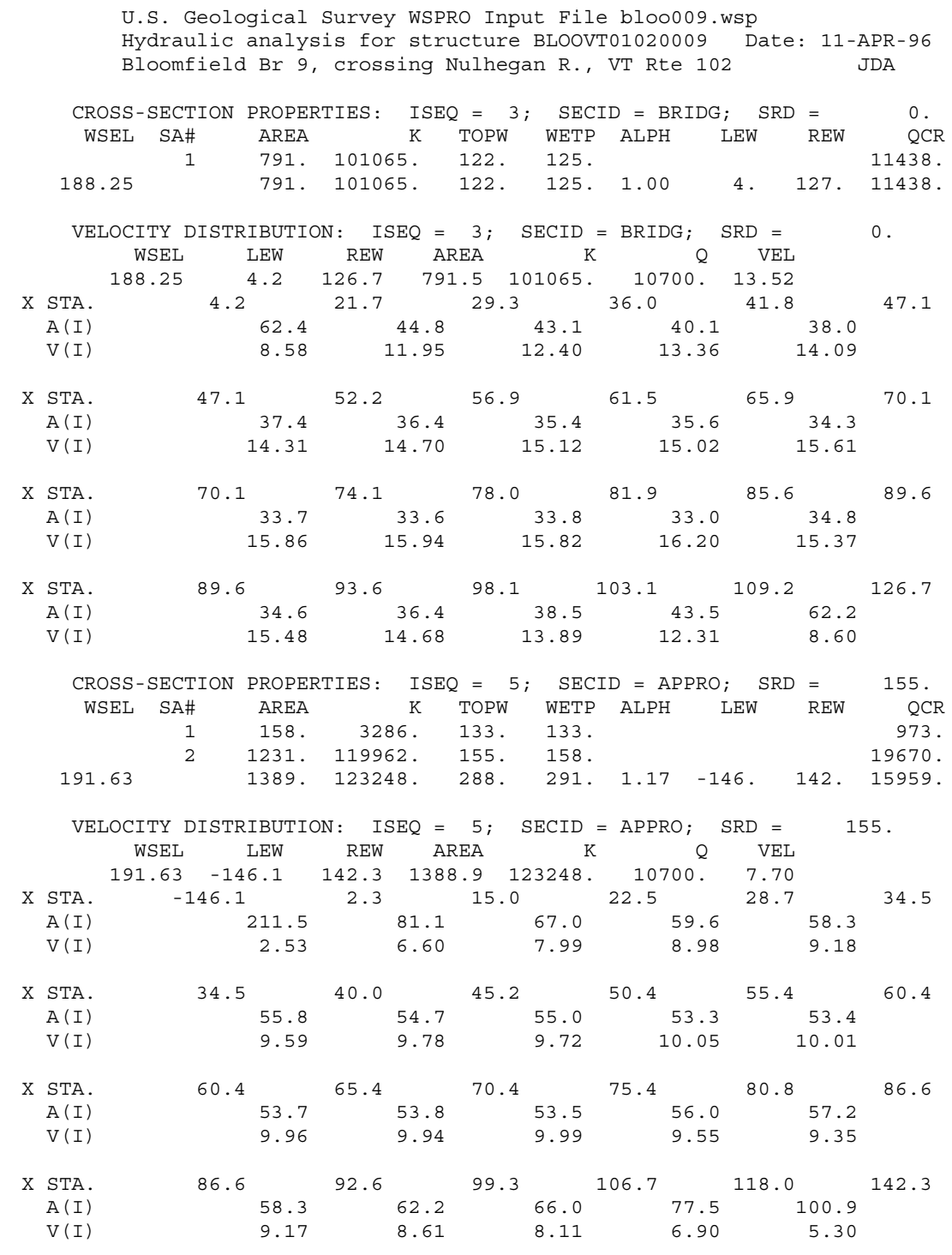


WSPRO OUTPUT FILE (continued)

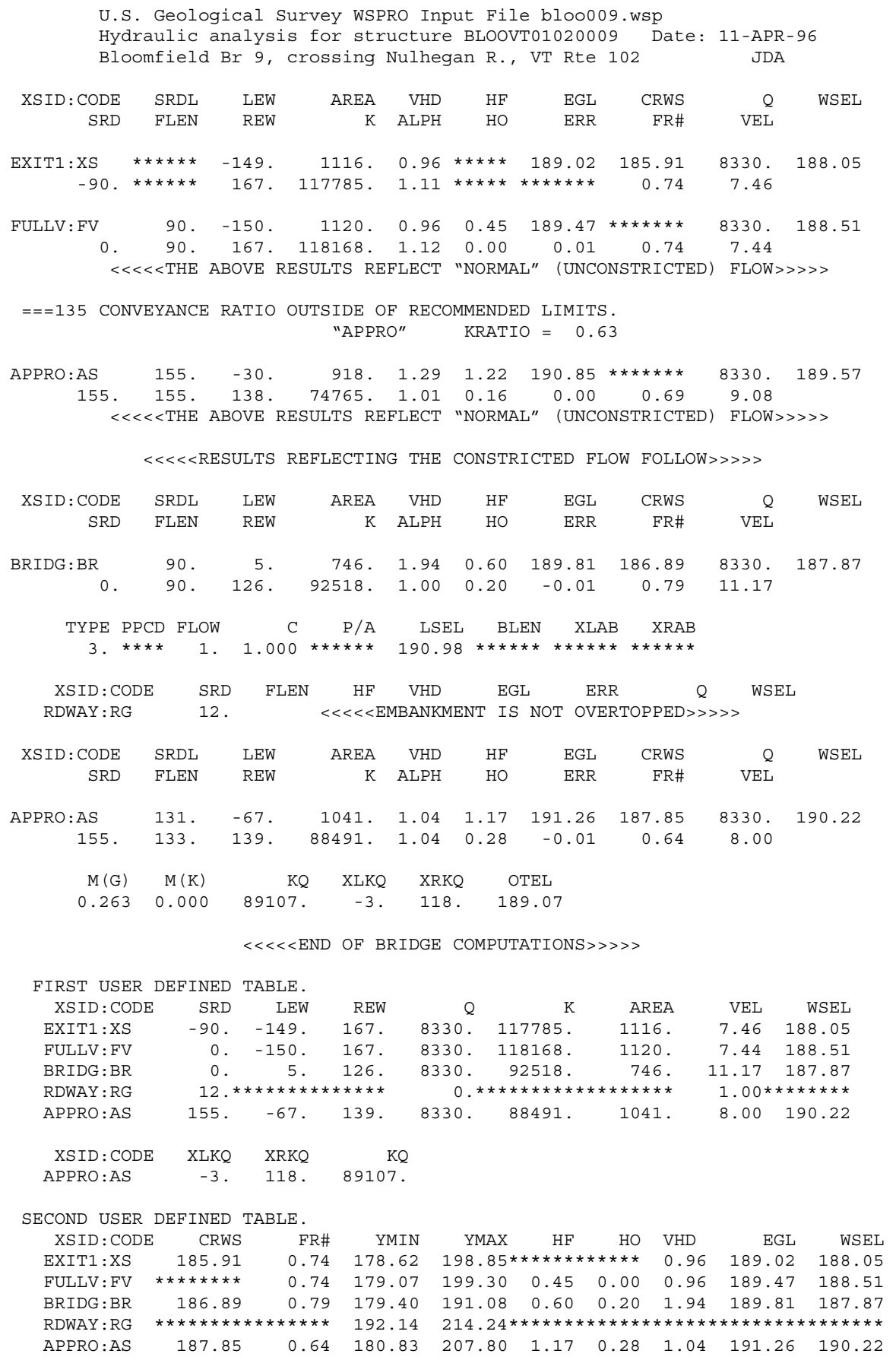


WSPRO OUTPUT FILE (continued)

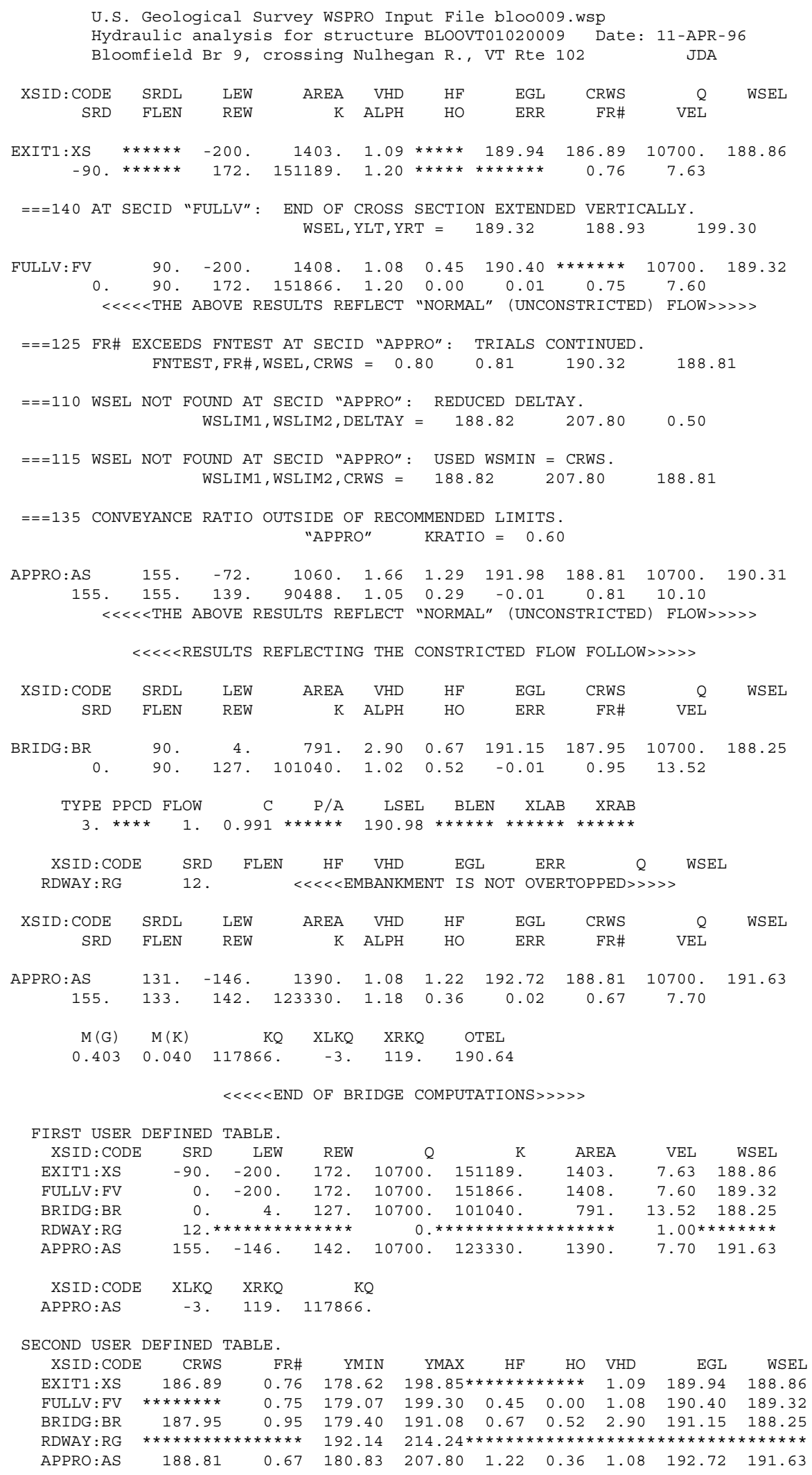




\section{APPENDIX C:}

\section{BED-MATERIAL PARTICLE-SIZE DISTRIBUTION}




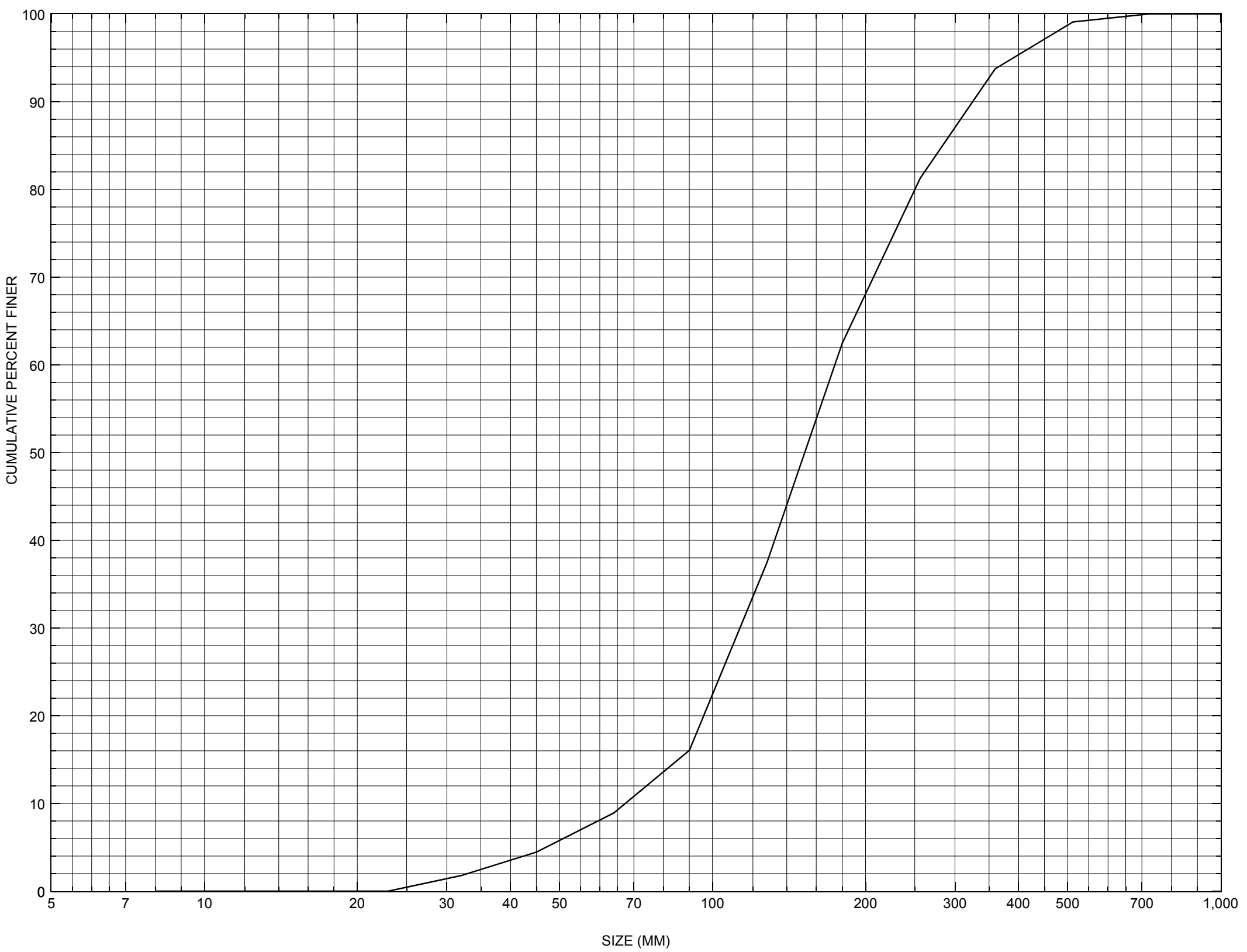

Appendix C. Bed material particle-size distribution for a pebble count in the channel approach of structure BLOOVT01020009, in Bloomfield, Vermont. 


\section{APPENDIX D: \\ HISTORICAL DATA FORM}




\section{Structure Number BLOOVT01020009}

\section{General Location Descriptive}

Data collected by (First Initial, Full last name) M. WEBER

Date $(M M / D D / Y Y) \_\mathbf{0 8} / \underline{\mathbf{0 4}} / \underline{\mathbf{9 4}}$

Highway District Number (I - 2; nn) $\mathbf{0 9}$

Town (FIPS place code; I - 4; nnnnn) $\mathbf{0 6 3 2 5}$

Waterway ( $I$ - 6) NULHEGAN RIVER

Route Number VT102

Topographic Map Bloomfield

Latitude (I - 16; nnnn.n) $\mathbf{4 4 4 5 1}$
County (FIPS county code; I - 3; nnn)

Mile marker (I - 11; nnn.nnn) $\mathbf{0 0 0 1 7 0}$

Road Name (I - 7): -

Vicinity (I - 9) 0.2 MI S JCT. VT.105

Hydrologic Unit Code: $\mathbf{0 1 0 8 0 1 0 1}$

Longitude (i - 17; nnnnn.n) $\mathbf{7 1 3 7 9}$

\section{Select Federal Inventory Codes}

FHWA Structure Number (I - 8) $\mathbf{2 0 0 2 7 1 0 0 0 9 0 5 0 3}$

Maintenance responsibility $(I-21 ; n n) \_$01_ Maximum span length $(I-48$; nnnn) $\underline{\mathbf{0 1 3 0}}$

Year built (I-27; YYYY) 1937

Structure length (I - 49; nnnnnn) $\underline{\mathbf{0 0 0 1 3 4}}$

Average daily traffic, ADT (I - 29; nnnnnn) $\mathbf{0 0 0 3 6 0}$ Deck Width (I - 52; nn.n) 244

Year of ADT (I - 30; YY) $\mathbf{9 2}$

Channel \& Protection $(I-61 ; n) \underline{\mathbf{8}}$

Opening skew to Roadway $(I-34 ; n n) \quad \mathbf{0 0}$

Waterway adequacy $(I-71 ; n)$

Operational status $(I-41 ; X)$ A

Underwater Inspection Frequency $(I-92 B ; X Y Y) \_\mathbf{N}$

Structure type (I - 43; nnn) $\mathbf{3 1 0}$

Year Reconstructed (I - 106) $\mathbf{0 0 0 0}$

Approach span structure type $(I-44 ; n n n) \quad \mathbf{0 0 0}$ Clear span $(n n n . n f t)$

Number of spans (I - 45; nnn) $\mathbf{0 0 1}$

Vertical clearance from streambed (nnn.n ft) $\underline{\mathbf{0 1 0 . 0}}$

Number of approach spans (I - 46; nnnn) $\mathbf{0 0 0 0}$

Waterway of full opening $\left(n n n . n \mathrm{ft}^{2}\right)$

Comments:

The bridge in the photos supplied with the bridge record looks much newer than 1937, renovation/reconstruction suspected. The existing structure is a steel truss type bridge. Structural inspection report of 10/ 21/93 indicated asphalt cracking over end joints and extensive rust on steel girders. The right abutment stem has heavy spalling and cracks in the floor beam. The stone fill at abutments is in good shape. 


\section{Bridge Hydrologic Data}

Is there hydrologic data available? $\mathbf{N}$ if No, type ctrl- $n$ VTAOT Drainage area $\left(\mathrm{mi}^{2}\right)^{2}$ : -

Terrain character:

Stream character \& type: -

Streambed material: Boulders, coarse gravel, cobbles

Discharge Data (cfs): $\quad \mathrm{Q}_{2.33}-$

$$
\mathrm{Q}_{50}-
$$

Record flood date $(M M / D D / Y Y):-$

$\begin{array}{ll}Q_{10 \_-} & Q_{25}- \\ Q_{100 \_-} & Q_{500-}-\end{array}$

Water surface elevation (ft): -

Estimated Discharge (cfs): Velocity at $\mathrm{Q}-$ (ft/s): -

Ice conditions (Heavy, Moderate, Light) : Light Debris (Heavy, Moderate, Light): Light

The stage increases to maximum highwater elevation (Rapidly, Not rapidly):

The stream response is (Flashy, Not flashy):

Describe any significant site conditions upstream or downstream that may influence the stream's stage: -

Watershed storage area (in percent): - $\%$

The watershed storage area is: - (1-mainly at the headwaters; 2- uniformly distributed; 3-immediatly upstream oi the site)

Water Surface Elevation Estimates for Existing Structure:

\begin{tabular}{|l|l|l|l|l|l|}
\hline Peak discharge frequency & $Q_{2.33}$ & $Q_{10}$ & $Q_{25}$ & $Q_{50}$ & $Q_{100}$ \\
Water surface elevation (ft)) & - & - & - & - & - \\
Velocity (ft/sec) & - & - & - & - & - \\
\hline
\end{tabular}

Long term stream bed changes: -

Is the roadway overtopped below the $\mathrm{Q}_{100}$ ? (Yes, No, Unknown): $\mathbf{U} \quad$ Frequency: Relief Elevation (ft): Discharge over roadway at $\mathrm{Q}_{100}\left(\mathrm{ft}^{3} / \mathrm{sec}\right)$ :

Are there other structures nearby? (Yes, No, Unknown): $\mathbf{U}$ Upstream distance (miles): Town: If No or Unknown, type ctrl-n os Highway No. : Structure No. : Year Built:

Clear span (ft): Clear Height (ft): Full Waterway $\left(f^{2}\right)$ : 
Downstream distance (miles): Town: Year Built:

Highway No. : Structure No. : Structure Type:

Clear span (ft): Clear Height $(f t)$ : Full Waterway $\left(f^{2}\right):$

Comments:

\section{USGS Watershed Data}

Watershed Hydrographic Data

Drainage area $(D A) \underline{143.61} \mathrm{mi}^{2}$ Lake and pond area

8.06 $\mathrm{mi}^{2}$

Watershed storage (ST)

Bridge site elevation 900 5.6 $\%$

Main channel length $\mathbf{2 1 . 2 3}$ $\mathrm{ft}$

Headwater elevation

2948 $\mathrm{ft}$ $10 \%$ channel length elevation $\mathbf{9 4 0}$ $\mathrm{ft} \quad 85 \%$ channel length elevation $\mathrm{ft}$

Main channel slope (S) $22.61 \quad \mathrm{ft} / \mathrm{mi}$

Watershed Precipitation Data

Average site precipitation in Average headwater precipitation in

Maximum 2yr-24hr precipitation event $(124,2)$ in

Average seasonal snowfall (Sn) $\mathrm{ft}$ 


\section{Bridge Plan Data}

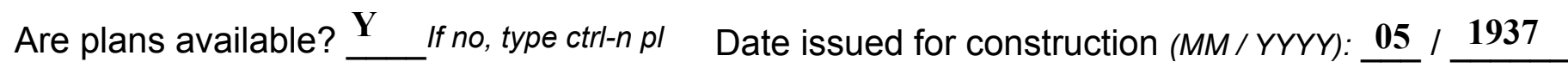
Project Number $231-\mathrm{L}$

Minimum channel bed elevation: 181.0

Low superstructure elevation: USLAB 191.08 DSLAB 191.08 USRAB 191.08 DSRAB 191.08

Benchmark location description:

BM, wash boring on top of stone at end of downstream left wingwall, elevation 192.40.

Reference Point (MSL, Arbitrary, Other): Arbitrary $\quad$ Datum (NAD27, NAD83, Other): Arbitrary Foundation Type: 1

If 1: Footing Thickness $\mathbf{2 . 3} \quad$ Footing bottom elevation: $1 \mathbf{1 8 2 . *}$

If 2: Pile Type: ___ (1-Wood; 2-Steel or metal; 3-Concrete) Approximate pile driven length: -

If 3: Footing bottom elevation: -

Is boring information available? $\mathbf{Y}$ If no, type ctrl-n bi Number of borings taken: 2

Foundation Material Type: 1 (1-regolith, 2-bedrock, 3-unknown)

Briefly describe material at foundation bottom elevation or around piles:

COARSE GRAVEL AND BOULDERS.

Comments:

*The left abutment bottom of footing is shown at elevation $\mathbf{1 8 1 . 0 8}$ and that of the right abutment is shown at elevation 182.83. 


\section{Cross-sectional Data}

Is cross-sectional data available? $\underline{\mathbf{Y}}$ If no, type ctrl-n xs

Source (FEMA, VTAOT, Other)? VTAOT

Comments: Orientation of the cross sections is inconsistent with any cross section data surveyed for this study and is not comparable. Data was not retrieved.

\begin{tabular}{|l|l|l|l|l|l|l|l|l|l|l|l|}
\hline Station & & & & & & & & & & & \\
\hline Feature & & & & & & & & & & & \\
\hline $\begin{array}{l}\text { Low cord } \\
\text { elevation }\end{array}$ & & & & & & & & & & & \\
\hline $\begin{array}{l}\text { Bed } \\
\text { elevation }\end{array}$ & & & & & & & & & & & \\
\hline $\begin{array}{l}\text { Low cord to } \\
\text { bed length }\end{array}$ & & & & & & & & & & & \\
\hline Station & & & & & & & & & & & \\
\hline Feature & & & & & & & & & & & \\
\hline $\begin{array}{l}\text { Low cord } \\
\text { elevation }\end{array}$ & & & & & & & & & & & \\
\hline $\begin{array}{l}\text { Bed } \\
\text { elevation }\end{array}$ & & & & & & & & & & & \\
\hline $\begin{array}{l}\text { Low cord to } \\
\text { bed length }\end{array}$ & & & & & & & & & & & \\
\hline
\end{tabular}

Source (FEMA, VTAOT, Other)?

Comments:

\begin{tabular}{|l|l|l|l|l|l|l|l|l|l|l|l|}
\hline Station & & & & & & & & & & & \\
\hline Feature & & & & & & & & & & & \\
\hline $\begin{array}{l}\text { Low cord } \\
\text { elevation }\end{array}$ & & & & & & & & & & & \\
\hline $\begin{array}{l}\text { Bed } \\
\text { elevation }\end{array}$ & & & & & & & & & & & \\
\hline $\begin{array}{l}\text { Low cord to } \\
\text { bed length }\end{array}$ & & & & & & & & & & & \\
\hline Station & & & & & & & & & & & \\
\hline Feature & & & & & & & & & & & \\
\hline $\begin{array}{l}\text { Low cord } \\
\text { elevation }\end{array}$ & & & & & & & & & & & \\
\hline $\begin{array}{l}\text { Bed } \\
\text { elevation }\end{array}$ & & & & & & & & & & & \\
\hline $\begin{array}{l}\text { Low cord to } \\
\text { bed length }\end{array}$ & & & & & & & & & & & \\
\hline
\end{tabular}




\section{APPENDIX E: \\ LEVEL I DATA FORM}


U. S. Geological Survey

Bridge Field Data Collection and Processing Form

Qa/Qc Check by: MAI Date: $\underline{10 / 24 / 95}$

\section{Structure Number}

BLOOVT01020009

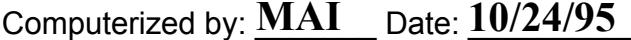

Reviewd by: JDA Date: $\underline{01 / 08 / 97}$

\section{A. General Location Descriptive}

1. Data collected by (First Initial, Full last name) $\underline{\mathbf{E}}$. Boehmler

2. Highway District Number $\mathbf{0 9}$

Mile marker 000170

County Essex (009)

Town Bloomfield (06325)

Waterway $(I$ - 6) Nulhegan River

Route Number VT 102

Road Name -

Hydrologic Unit Code: $\mathbf{0 1 0 8 0 1 0 1}$

3. Descriptive comments:

Located 0.2 miles south of the junction with state route 105. Jim Degnan assisted with the following assessment.

\section{B. Bridge Deck Observations}
4. Surface cover... LBUS 6
RBUS 6
LBDS 6
RBDS 5
Overall 6

(2b us,ds,lb,rb: 1- Urban; 2- Suburban; 3- Row crops; 4- Pasture; 5- Shrub- and brushland; 6- Forest; 7- Wetland)
5. Ambient water surface... US $\underline{2}$
UB 2
DS $\underline{2}$
(1- pool; 2- riffle)

6. Bridge structure type 1 (1- single span; 2- multiple span; 3- single arch; 4- multiple arch; 5-cylindrical culvert; 6- box culvert; or 7- other)
7. Bridge length $\mathbf{1 3 4 . 0}$
(feet)
Span length 130.0 (feet)
Bridge width 24.4 (feet)

\section{Road approach to bridge:}
8. LB 1 RB 1
( 0 even, 1- lower, 2- higher)
9. LB 1
RB 1
(1- Paved, 2- Not paved)

10. Embankment slope (run / rise in feet / foot):

US left

2.2:1

US right --

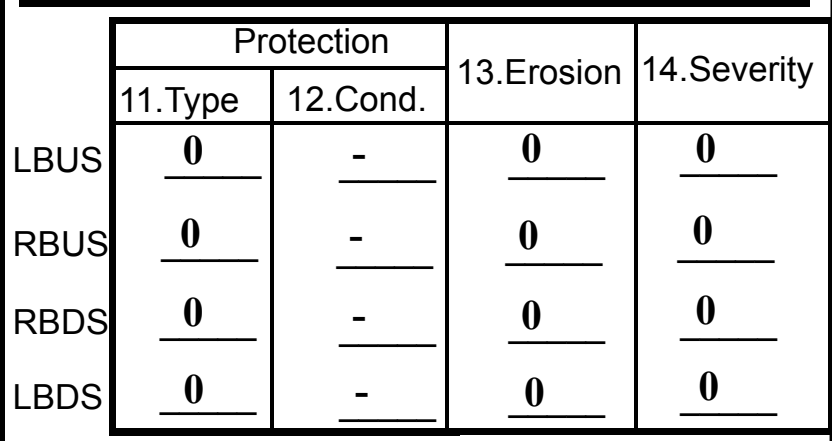

Bank protection types: 0- none; 1- < 12 inches;

2- < 36 inches; $3-<48$ inches;

4- $<60$ inches; 5- wall / artificial levee

Bank protection conditions: 1- good; 2- slumped;

3- eroded; 4- failed

Erosion: 0 - none; 1- channel erosion; 2-

road wash; 3- both; 4- other

Erosion Severity: 0 - none; 1- slight; 2- moderate;

Channel approach to bridge (BF):

15. Angle of approach: $\mathbf{5}$

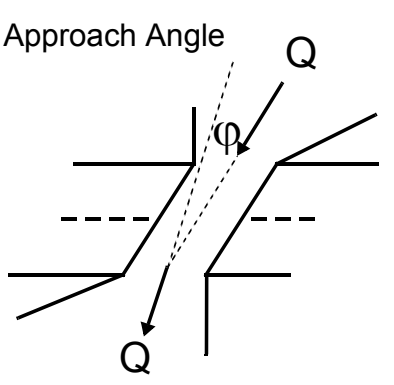

17. Channel impact zone 1 :

Where? RB (LB, RB)

Range? 52 feet US

Channel impact zone 2:

Where? (LB, RB)

Range? feet (US, UB, DS) to feet

16. Bridge skew: 25 Bridge Skew Angle

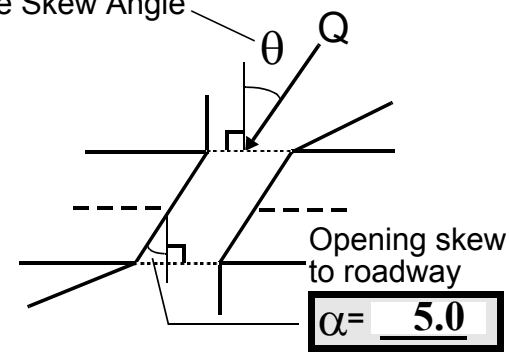

\section{Exist? $\mathbf{Y}(Y$ or $N)$}

Severity 1

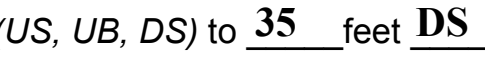

Exist? $\underline{\mathbf{N}}(\mathrm{Y}$ or $N)$

Severity

Impact Severity: 0- none to very slight; 1- Slight; 2- Moderate; 3- Severe 
18. Bridge Type: $\mathbf{3 / 1} \mathbf{b}$

1a- Vertical abutments with wingwalls

1 b- Vertical abutments without wingwalls

2- Vertical abutments and wingwalls, sloping embankment Wingwalls perpendicular to abut. face

3- Spill through abutments

4- Sloping embankment, vertical wingwalls and abutments

Wingwall angle less than $90^{\circ}$.

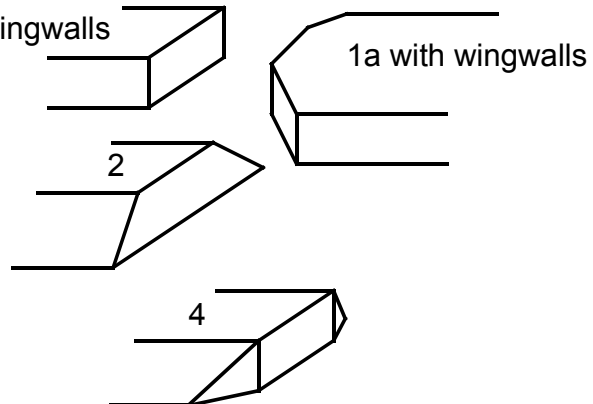

19. Bridge Deck Comments (surface cover variations, measured bridge and span lengths, bridge type variations, approach overflow width, etc.)

4. The predominant surface cover is forest except for on the downstream right bank which has some shrubs along the immediate bank and sparse trees and grass on the overbank.

7. Measured bridge dimensions matched the historical values.

\section{Upstream Channel Assessment}

\begin{tabular}{|c|c|c|c|c|c|c|c|c|c|c|}
\hline \multicolumn{5}{|c|}{ 21. Bank height (BF) 22. Bank angle (BF) } & \multicolumn{2}{|c|}{ 26. \% Veg. cover (BF) } & \multicolumn{2}{|c|}{ 27. Bank material (BF) } & \multicolumn{2}{|c|}{ 28. Bank erosion (BF } \\
\hline 20. SRD & LB & RB & LB & RB & LB & RB & LB & RB & LB & RB \\
\hline 152.5 & 6.0 & & & 3.5 & 4 & 4 & 3245 & 3245 & 1 & 1 \\
\hline 23. Bank & & & 24. $C$ & eel width & 25.0 & 25. Tha & weg deptr & 68.5 & 9. Bed & 435 \\
\hline
\end{tabular}

30 .Bank protection type:

LB 1

RB 0

31. Bank protection condition: LB 1

RB -

SRD - Section ref. dist. to US face \% Vegetation (Veg) cover: 1- 0 to 25\%; 2- 26 to 50\%; 3- 51 to $75 \%$; 4- 76 to $100 \%$

Bed and bank Material: 0- organics; 1- silt / clay, < 1/16mm; 2- sand, 1/16 - 2mm; 3- gravel, 2 - 64mm;

4- cobble, 64 - 256mm; 5- boulder, > 256mm; 6- bedrock; 7- manmade

Bank Erosion: 0- not evident; 1- light fluvial; 2- moderate fluvial; 3- heavy fluvial / mass wasting

Bank protection types: 0- absent; 1- < 12 inches; 2- < 36 inches; 3- < 48 inches; 4- < 60 inches; 5- wall / artificial levee

Bank protection conditions: 1-good; 2- slumped; 3- eroded; 4- failed

32. Comments (bank material variation, minor inflows, protection extent, etc.):

27. Bank material consists of gravel, sand, cobble, and some boulders.

29. Bed material consists of cobble, gravel, and boulders.

30. Left bank protection extends 70 to 220 feet upstream. The protection appears to be native material pushed up on the bank and served as protection for a previous structure. There is a pile of stone fill similar to that on the left bank across the channel from a remnant left abutment wall.

A scour hole has developed just DS from the stone fill pile on the right bank. 
38. Point or side bar comments (Circle Point or Side; Note additional bars, material variation, status, etc.):

Point bar consisting of gravel, cobble, and boulders. The US end is more cobble boulder grading down to gravel with some sand at the very highest part of the bar. Shrubs, brush, and small trees are growing in the sandy part of the bar.

39. Is a cut-bank present? $\underline{\mathbf{Y}}$ ( $Y$ or if $N$ type ctrl-n $c b)$ 40. Where? $\underline{\mathbf{R B}}$ (LB or RB)

41. Mid-bank distance: 35 42. Cut bank extent: 71

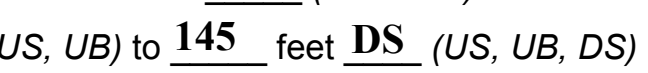

43. Bank damage: 2 (1- eroded and/or creep; 2- slip failure; 3- block failure)

44. Cut bank comments (eg. additional cut banks, protection condition, etc.):

Bed material at the toe of riprap along the right abutment has eroded primarily at the DS end. A couple of the stones have slumped. This cut bank extends under the bridge with the stones protecting the bank.

\section{Is channel scour present? $\mathbf{Y}$ ( $Y$ or if $N$ type ctrl-n cs) $\quad$ 46. Mid-scour distance: $\mathbf{2 5 0}$}

47. Scour dimensions: Length $\underline{105}$ Width $\underline{45}$ Depth: $\underline{3.5}$ Position $\underline{70} \%$ LB to $\underline{95} \%$ RB

48. Scour comments (eg. additional scour areas, local scouring process, etc.):

This localized scour hole is on the right bank side just DS of the old abutment location. Ambient depth of the channel is 1.0 feet.

49. Are there major confluences? $\mathbf{N}$

51. Confluence 1: Distance Confluence 2: Distance -

NO MAJOR CONFLUENCES
( $Y$ or if $N$ type ctrl-n $m c$ )

52. Enters on -

Enters on ( $L B$ or $R B$ ) (LB or RB)
50. How many? -

53. Type(1- perennial; 2- ephemeral)

Type (1-perennial; 2- ephemeral)

NO MAJOR CONFLUENCES

\section{Under Bridge Channel Assessment}

55. Channel restraint (BF)? LB 2

\begin{tabular}{|ccccc}
\hline \multicolumn{2}{|c}{ 56. Height (BF) } & \multicolumn{3}{c}{57 Angle (BF) } \\
LB & RB & LB & RB \\
$\mathbf{9 5 . 0}$ & & & $\mathbf{1 . 5}$ & \\
\hline
\end{tabular}
(1- natural bank; 2- abutment; 3- artificial levee)
58. Bank width (BF)
59. Channel width (Amb)
60. Thalweg depth (Amb) $\mathbf{9 0 . 0}$

\begin{tabular}{lc} 
61. Material (BF) \\
LB & RB \\
$\mathbf{2}$ & $\mathbf{7}$ \\
\hline
\end{tabular}

62. Erosion (BF)

LB RB

7

63. Bed Material -

Bed and bank Material: 0- organics; 1- silt / clay, < 1/16mm; 2- sand, 1/16 - 2mm; 3- gravel, 2 - 64mm; 4- cobble, 64 - 256mm; 5- boulder, > 256mm; 6- bedrock; 7- manmade

Bank Erosion: 0- not evident; 1- light fluvial; 2- moderate fluvial; 3- heavy fluvial / mass wasting

64. Comments (bank material variation, minor inflows, protection extent, etc.):

435

Bed material consists of cobble, gravel, and boulders. 
65. Debris and Ice Is there debris accumulation?

(Yor $N)$ 66. Where? $\underline{Y}$

(1- Upstream; 2- At bridge; 3- Both)

67. Debris Potential 1 (1-Low; 2-Moderate; 3- High)

68. Capture Efficiency 2

(1-Low; 2- Moderate; 3- High)

69. Is there evidence of ice build-up? 1 (Y or $N)$

Ice Blockage Potential $\mathbf{N}$

(1-Low; 2- Moderate; 3- High)

70. Debris and Ice Comments:

1

Lots of trees on the banks upstream with potential for bank instability and erosion. The bridge opening will accommodate debris flow.

\begin{tabular}{|l|c|c|c|c|c|c|c|c|}
\hline Abutments & $\begin{array}{c}\text { 71. Attack } \\
\angle \text { (BF) }\end{array}$ & $\begin{array}{c}\text { 72. Slope } \angle \\
\text { (Qmax) }\end{array}$ & $\begin{array}{c}\text { 73. Toe } \\
\text { loc. (BF) }\end{array}$ & $\begin{array}{c}\text { 74. Scour } \\
\text { Condition }\end{array}$ & $\begin{array}{c}75 . \text { Scour } \\
\text { depth }\end{array}$ & $\begin{array}{c}\text { 76. Exposure } \\
\text { depth }\end{array}$ & 77. Material & 78. Length \\
\hline LABUT & & $\mathbf{0}$ & $\mathbf{4 5}$ & $\mathbf{0}$ & $\mathbf{0}$ & $\mathbf{0}$ & $\mathbf{0}$ & $\mathbf{9 0 . 0}$ \\
\hline RABUT & $\mathbf{1}$ & $\mathbf{2 5}$ & $\mathbf{3 5}$ & & & $\mathbf{2}$ & $\mathbf{0}$ & $\mathbf{1 2 9 . 0}$ \\
\hline
\end{tabular}

Pushed: $L B$ or RB

Toe Location (Loc.): 0- even, 1- set back, 2- protrudes

Scour cond.: 0- not evident; 1- evident (comment); 2- footing exposed; 3-undermined footing; 4- piling exposed; 5- settled; 6- failed

Materials: 1- Concrete; 2- Stone masonry or drywall; 3- steel or metal; 4- wood

79. Abutment comments (eg. undermined penetration, unusual scour processes, debris, etc.):

$\mathbf{0}$

0

1

The concrete abutments are visible at the top of the riprapped spill-through slopes.

80. Wingwalls:

Exist? Material? Scour Scour Exposure $\begin{aligned} & 81 . \\ & \text { Angle? Length? }\end{aligned}$ Condition? depth? depth?

USLWW:

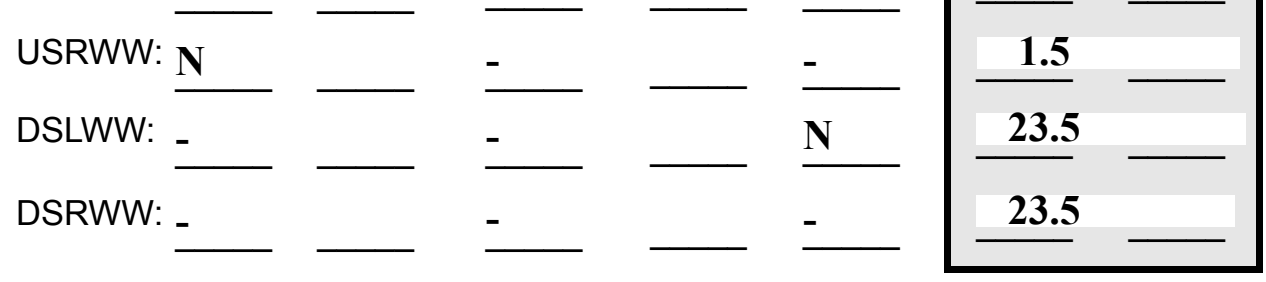

Wingwall materials: 1- Concrete; 2- Stone masonry or drywall; 3- steel or metal; 4- wood

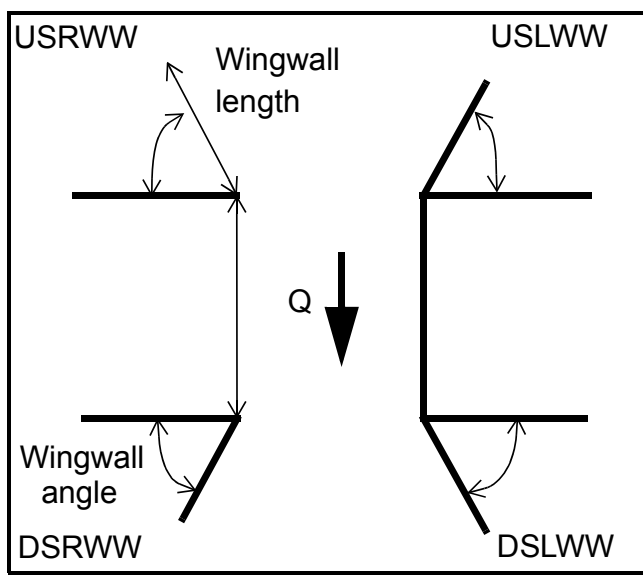

82. Bank / Bridge Protection:

\begin{tabular}{|l|l|l|l|l|l|l|l|c|}
\hline Location & USLWW & USRWW & LABUT & RABUT & LB & RB & DSLWW & DSRWW \\
\hline Type & - & - & $\mathbf{N}$ & - & - & - & $\mathbf{1}$ & $\mathbf{1}$ \\
\hline Condition & $\mathbf{N}$ & - & - & - & - & - & $\mathbf{1}$ & $\mathbf{1}$ \\
\hline Extent & - & - & - & - & - & $\mathbf{3}$ & $\mathbf{3}$ & - \\
\hline
\end{tabular}

Bank / Bridge protection types: 0- absent; 1- < 12 inches; 2- < 36 inches; 3- < 48 inches; 4- < 60 inches; 
83. Wingwall and protection comments (eg. undermined penetration, unusual scour processes, etc.):

-
-
-
-
-
-
-
-

\section{Piers:}

84. Are there piers? (Y or if $N$ type ctrl-n pr)

\begin{tabular}{|l|l|l|l|l|l|l|l|}
\hline \multirow{2}{*}{$\begin{array}{l}85 . \\
\text { Pier no. }\end{array}$} & \multicolumn{3}{|c|}{ width (w) feet } & \multicolumn{3}{c|}{ elevation (e) feet } \\
\cline { 2 - 9 } & w1 & w2 & w3 & e@w1 & e@w2 & e@w3 \\
\hline Pier 1 & - & - & - & - & - & - \\
\hline Pier 2 & - & - & - & - & - & - \\
\hline Pier 3 & - & - & - & - & - & - \\
\hline Pier 4 & - & - & - & - & - & - \\
\hline
\end{tabular}

\begin{tabular}{|l|l|l|l|l|}
\hline Level 1 Pier Descr. & 1 & \multicolumn{1}{|c|}{2} & 3 & \multicolumn{1}{|c|}{} \\
\hline 86. Location (BF) & & - & - & - \\
\hline 87. Type & & - & - & - \\
\hline 88. Material & & - & - & - \\
\hline 89. Shape & & - & - & - \\
\hline 90. Inclined? & & - & - & - \\
\hline 91. Attack $\angle$ (BF) & & - & - & - \\
\hline 92. Pushed & & - & - & - \\
\hline 93. Length (feet) & - & - & - & - \\
\hline 94. \# of piles & & - & - & - \\
\hline 95. Cross-members & & - & - & - \\
\hline 96. Scour Condition & & - & - & - \\
\hline 97. Scour depth & $\mathbf{N}$ & - & - & - \\
\hline 98. Exposure depth & - & - & - & - \\
\hline
\end{tabular}

LFP, LTB, LB, MCL, MCM, MCR, RB, RTB, RFP

1- Solid pier, 2- column, 3- bent

1-Wood; 2- concrete; 3- metal; 4- stone

1- Round; 2- Square; 3- Pointed

Y-yes; $N$ - no

$L B$ or $R B$

0- none; 1- laterals; 2- diagonals; 3- both

0- not evident; 1- evident (comment);

2- footing exposed; 3- piling exposed;

4- undermined footing; 5- settled; 6- failed 
99. Pier comments (eg. undermined penetration, protection and protection extent, unusual scour processes, etc.):

-
-
-
-
-
-
-
-
-
-

100.

\section{E. Downstream Channel Assessment}

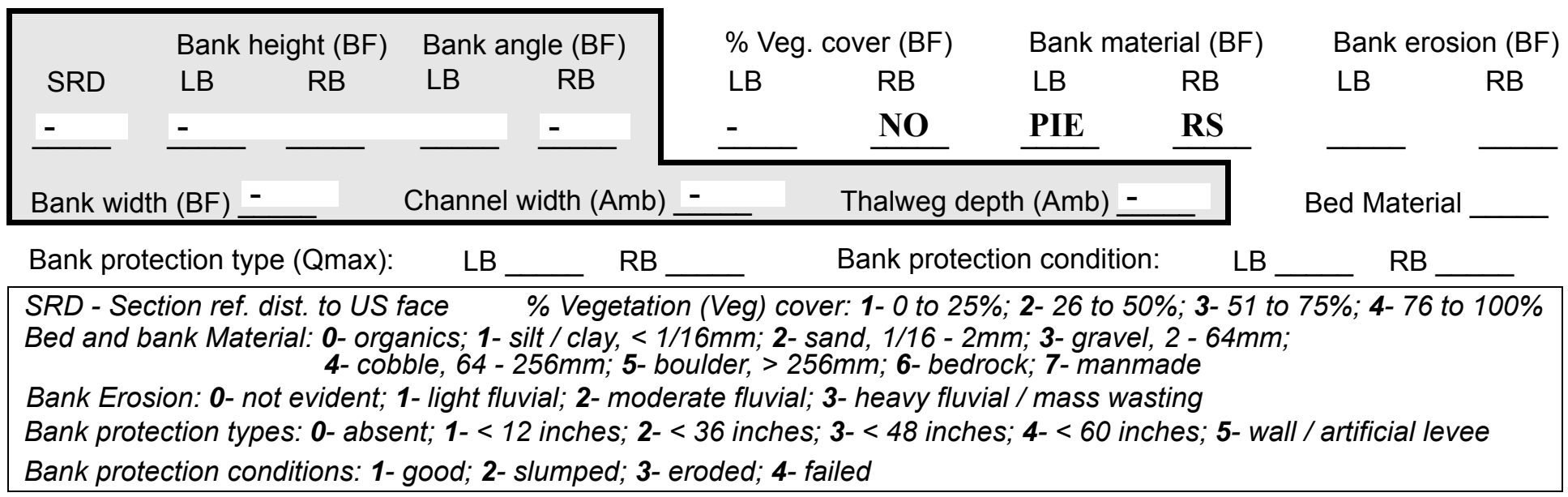

Comments (eg. bank material variation, minor inflows, protection extent, etc.):

4
1
345
345
0
2
435
0
3
-
2

Right bank protection has eroded and slipped down the bank extending 35 feet DS.

Bank material consists of gravel, cobble, and boulders.

101. Is a drop structure present? Be (Yor $N$, if $N$ type ctrl-n ds) 102. Distance: _ _ feet

103. Drop: - feet 104. Structure material: $\mathbf{d}$ (1- steel sheet pile; 2- wood pile; 3- concrete; 4- other) 105. Drop structure comments (eg. downstream scour depth):

material consists of cobble, gravel, and boulders. 
106. Point/Side bar present? (Y or N. if $N$ type ctrl-n pb)Mid-bar distance:

Mid-bar width:

Point bar extent: feet

(US, UB, DS) to feet (US, UB, DS) positioned $\underline{\mathbf{N}}$ $\%$ LB to $\%$ RB

Material: NO

Point or side bar comments (Circle Point or Side; note additional bars, material variation, status, etc.):

\section{DROP STRUCTURE}

Is a cut-bank present? (Y or if $N$ type ctrl- $n$ cb) Where? (LB or $R B)$

Mid-bank distance: $\underline{\mathbf{Y}}$

Cut bank extent: 0 feet $\mathbf{5 0}$ (US, UB, DS) to 79 feet $\underline{\mathbf{U S}}$ (US, UB, DS)

Bank damage: 210 (1- eroded and/or creep; 2- slip failure; 3- block failure)

Cut bank comments (eg. additional cut banks, protection condition, etc.):

DS

o

30

435

Is channel scour present? Th (Yor if $N$ type ctrl-n cs) Mid-scour distance: $\underline{\mathbf{e}}$

Scour dimensions: Length wid- Width est Depth: poin Positioned ton \%

Scour comments (eg. additional scour areas, local scouring process, etc.):

bar is at the DS bridge face. There is a little vegetation on the bar occupying less than $5 \%$ of the area. The bar ends at the confluence with the Connecticut River. The bar consist mostly of cobble and boulders.

$\mathbf{N}$

Are there major confluences? - (Y or if $N$ type ctrl-n $m c)$

Confluence 1: Distance -

Enters on (LB or $R B)$

How many? -

Confluence 2: Distance -

Enters on (LB or $R B)$

Type (1-perennial; 2- ephemeral)

Confluence comments (eg. confluence name):

Type $\mathbf{N O}$ (1- perennial; 2- ephemeral)

\section{CUT BANKS}

\section{F. Geomorphic Channel Assessment}

107. Stage of reach evolution

1- Constructed

2- Stable

3- Aggraded

4- Degraded

5- Laterally unstable

6- Vertically and laterally unstable 



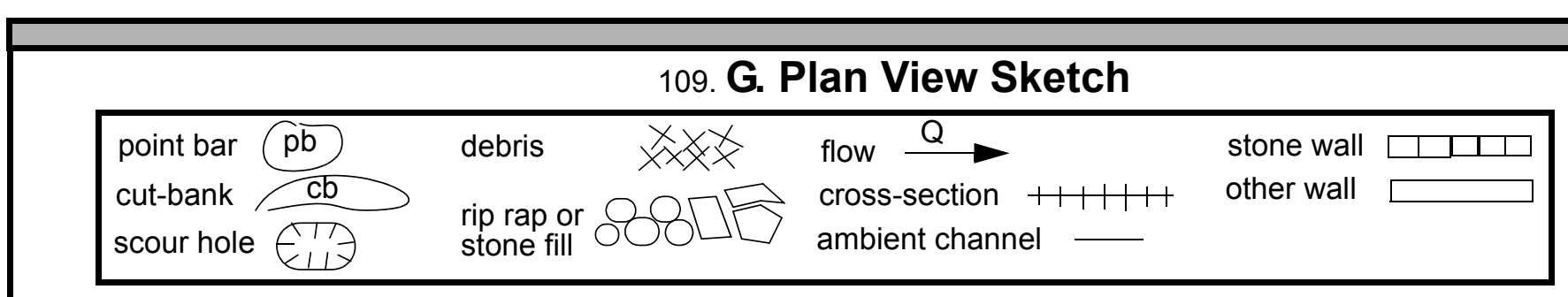

cut-bank cb

scour hole $\hat{E}$ rip rap or
stone fill cross-section $\mathrm{H}+\mathrm{H} 1 \mathrm{H}$ ambient channel other wall 
APPENDIX F:

SCOUR COMPUTATIONS 
SCOUR COMPUTATIONS

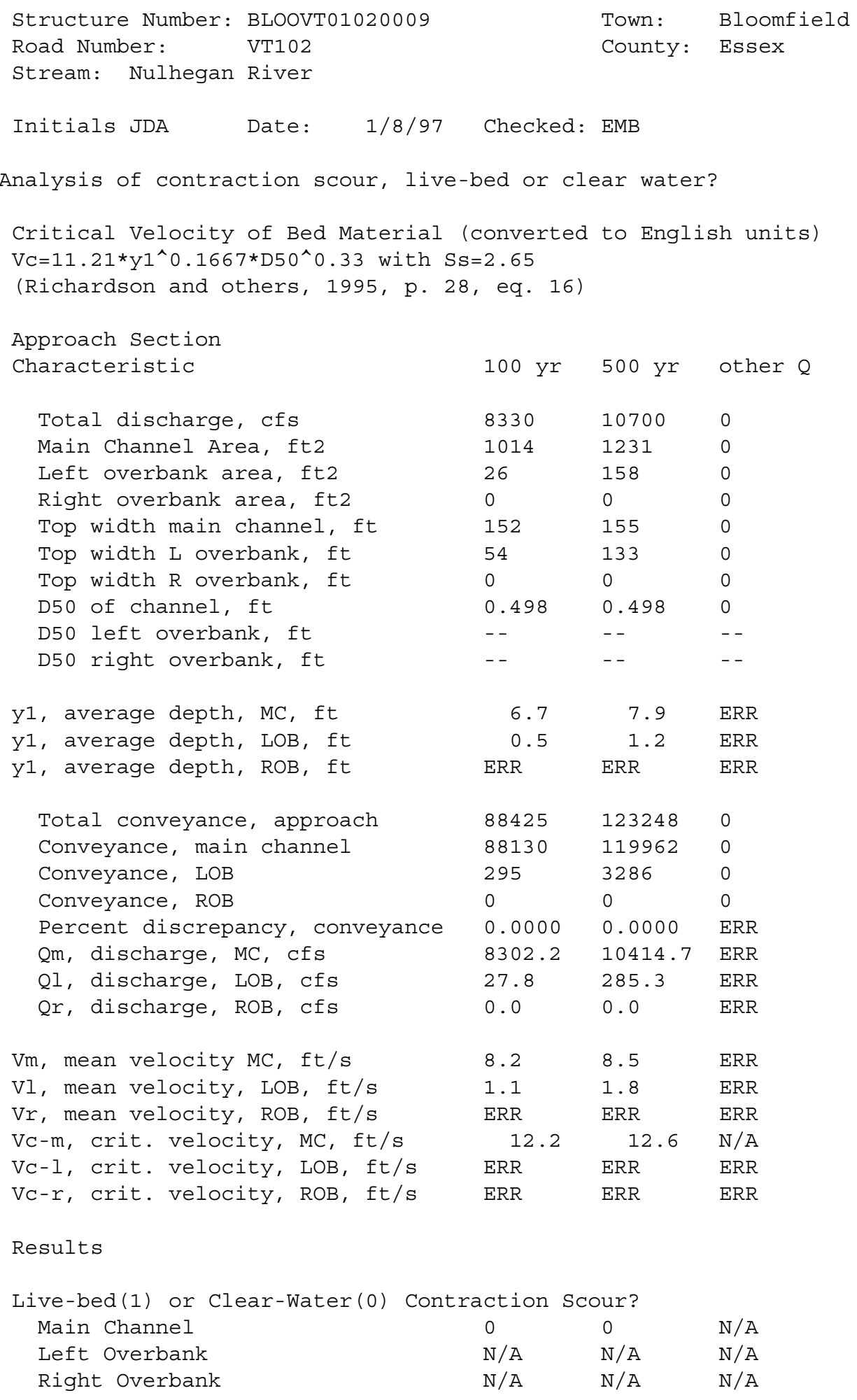


Clear water Contraction Scour in MAIN CHANNEL

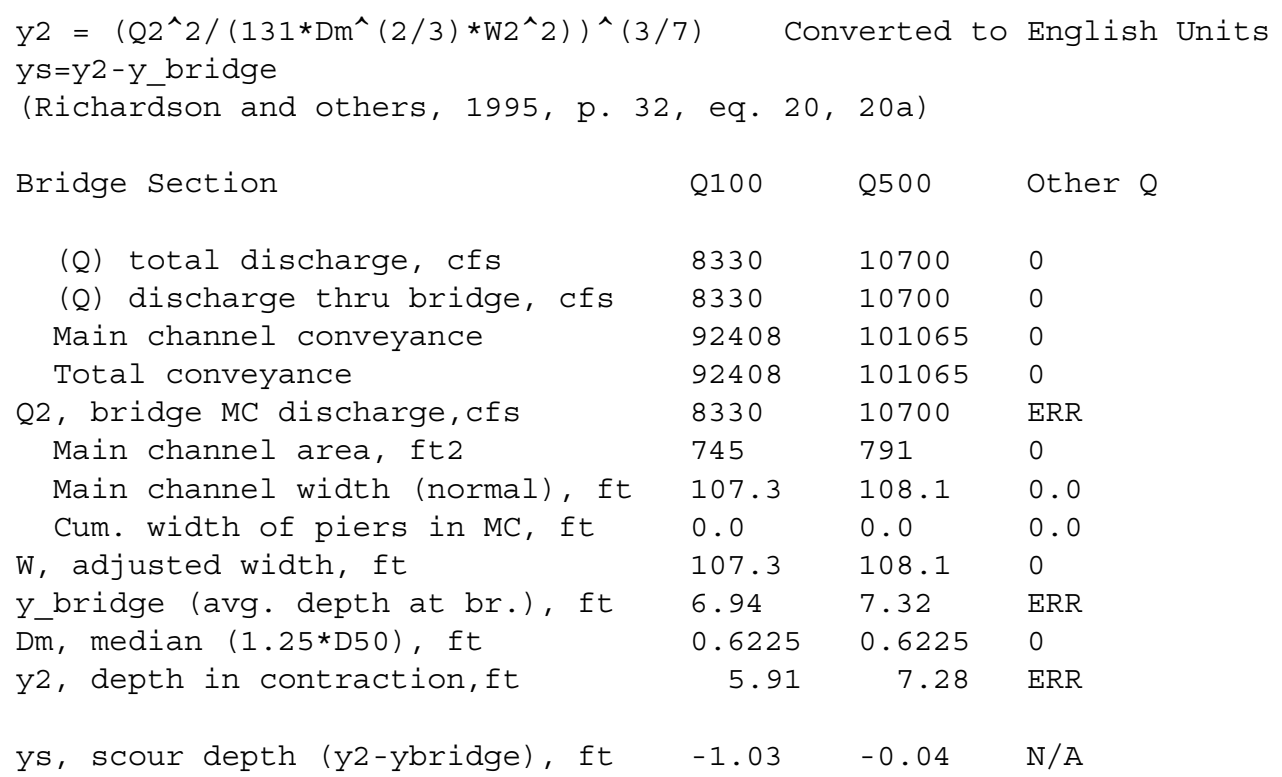

\begin{tabular}{|c|c|c|c|}
\hline \multicolumn{4}{|c|}{$\begin{array}{l}\text { Armoring } \\
\text { DC }=\left[\left(1.94 * \mathrm{~V}^{\wedge} 2\right) /(5.75 * \log (12.27 * \mathrm{Y} / \mathrm{D} 90))^{\wedge} 2\right] /[0.03 *(165-62.4)] \\
\text { Depth to Armoring }=3 *(1 / \mathrm{PC}-1) \\
\text { (Federal Highway Administration, 1993) }\end{array}$} \\
\hline Downstream bridge face property & $100-y r$ & $500-y r$ & Other Q \\
\hline Q, discharge thru bridge $\mathrm{MC}$, cfs & 8330 & 10700 & $\mathrm{~N} / \mathrm{A}$ \\
\hline Main channel area (DS), ft2 & 745 & 791 & 0 \\
\hline Main channel width (normal), ft & 107.3 & 108.1 & 0.0 \\
\hline Cum. width of piers, ft & 0.0 & 0.0 & 0.0 \\
\hline Adj. main channel width, ft & 107.3 & 108.1 & 0.0 \\
\hline D90, ft & 1.0663 & 1.0663 & 0.0000 \\
\hline D95, ft & 1.2823 & 1.2823 & 0.0000 \\
\hline Dc, critical grain size, ft & 0.6584 & 0.9410 & ERR \\
\hline Pc, Decimal percent coarser than Dc & 0.317 & 0.146 & 0.000 \\
\hline to armoring, ft & 4.26 & 16.51 & ERR \\
\hline
\end{tabular}


Abutment Scour

Froehlich's Abutment Scour

$\mathrm{Ys} / \mathrm{Y} 1=2.27 * \mathrm{~K} 1 * \mathrm{~K} 2 *\left(\mathrm{a}^{\prime} / \mathrm{Y} 1\right) \wedge 0.43 * \mathrm{Fr} 1 \wedge 0.61+1$

(Richardson and others, 1995, p. 48, eq. 28)

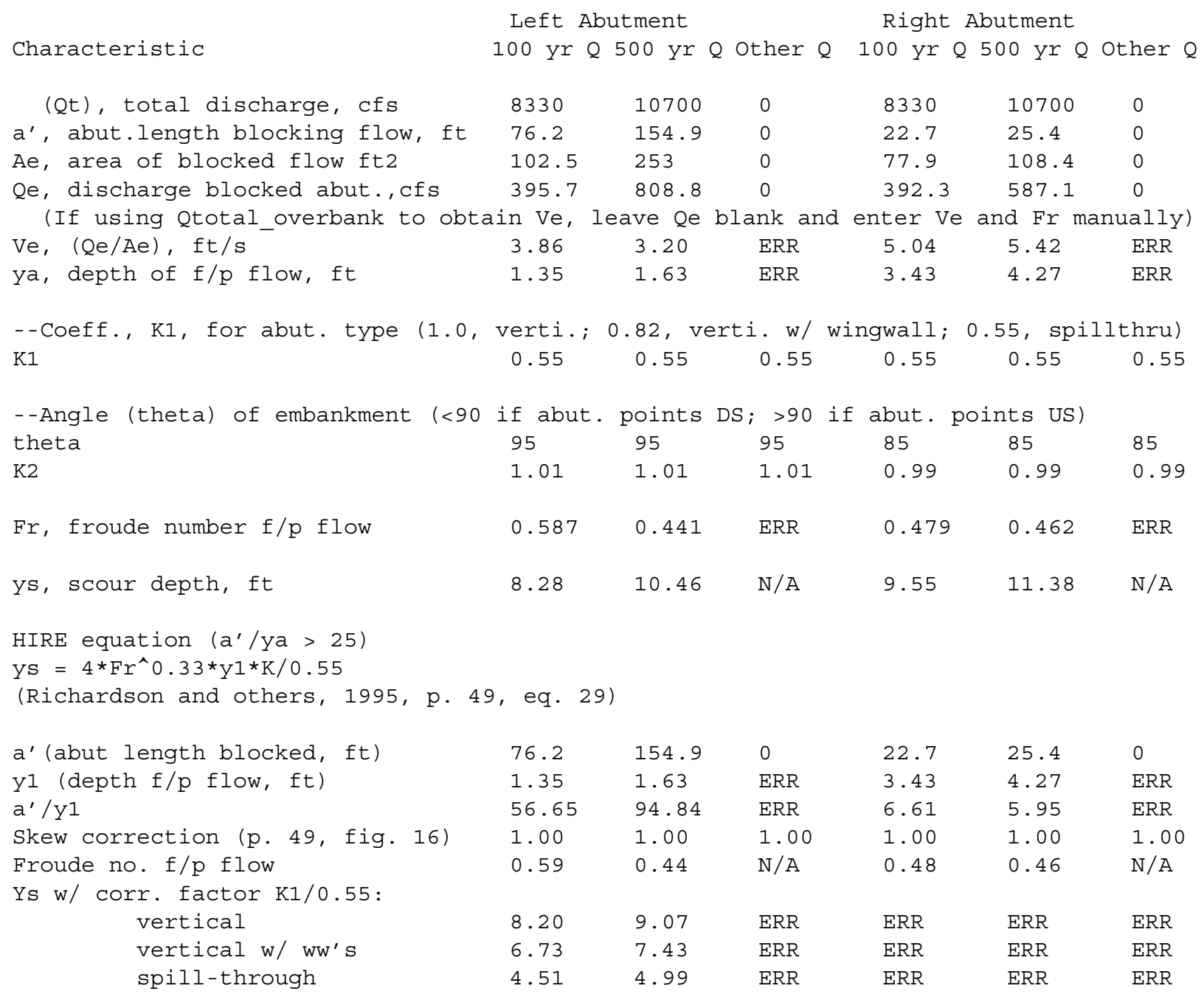




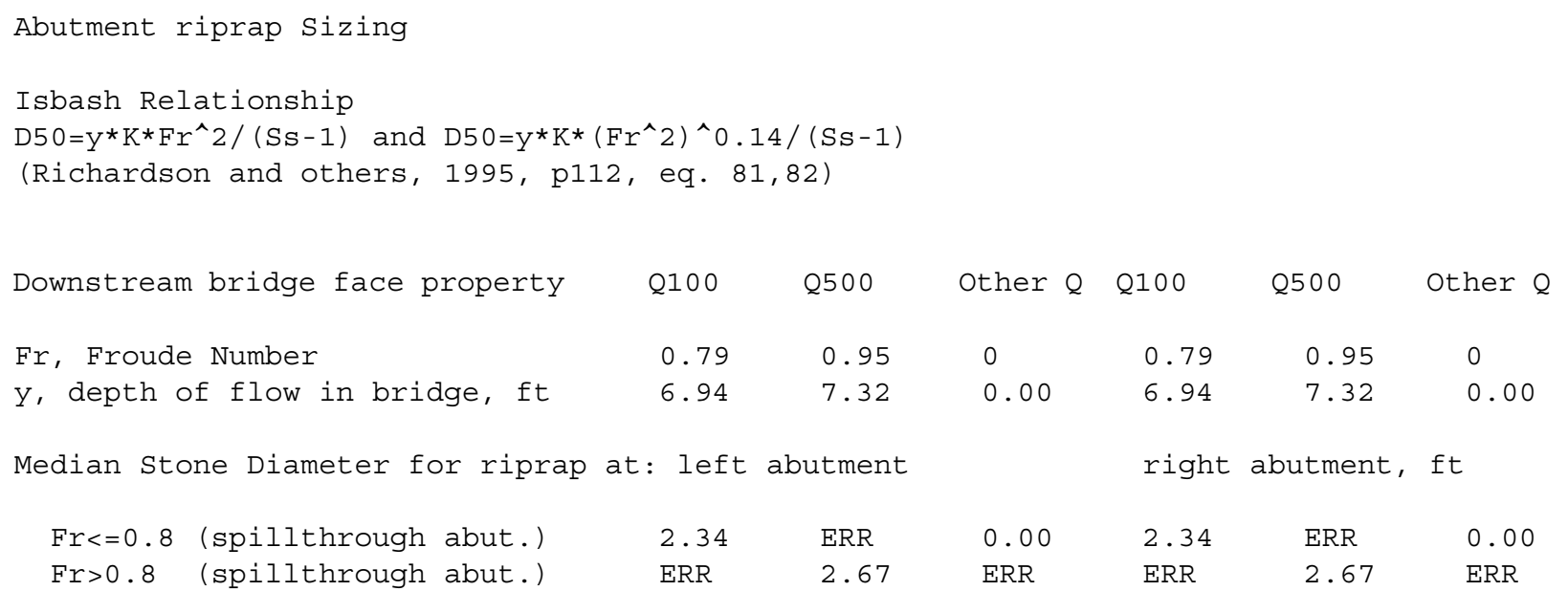

